\title{
3. MINERALOGY, CHEMISTRY, AND STABLE ISOTOPIC COMPOSITIONS OF HYDROTHERMALLY ALTERED SHEETED DIKES: ODP HOLE 504B, LEG 111
}

\author{
Jeffrey C. Alt, ${ }^{2}$ Thomas F. Anderson, ${ }^{3}$ Linda Bonnell, ${ }^{3}$ and Karlis Muehlenbach $s^{4}$
}

\begin{abstract}
During ODP Leg 111 Hole 504B was extended $212 \mathrm{~m}$ deeper into the sheeted dikes of oceanic Layer 2, for a total penetration of $1288 \mathrm{~m}$ within basement. Study of the mineralogy, chemistry, and stable isotopic compositions of the rocks recovered on Leg 111 has confirmed and extended the previous model for hydrothermal alteration at the site: axial greenschist hydrothermal metamorphism was followed by seawater recharge and subsequent off-axis alteration. The dikes are depleted in ${ }^{18} \mathrm{O}$ (mean $\delta^{18} \mathrm{O}=+5.1 \% 0 \pm 0.6 \%$ ) relative to fresh mid-ocean ridge basalt. Oxygen isotopic data on whole rocks and isolated secondary minerals indicate temperatures during axial metamorphism of $250^{\circ}-350^{\circ} \mathrm{C}$ and water/rock ratios about one. Increasing amounts of actinolite with depth in the dike section, however, suggest that temperatures increased downward in the dikes.

Pyrite + pyrrhotite + chalcopyrite + magnetite was the stable sulfide + oxide mineral assemblage during axial alteration, but these minerals partly re-equilibrated later at temperatures less than $200^{\circ} \mathrm{C}$. The dikes sampled on Leg 111 contain an average of $500 \mathrm{ppm}$ sulfur, slightly lower than igneous values. The $\delta^{34} \mathrm{~S}$ values of sulfide average $0 \%$, which indicates the presence of basaltic sulfide and incorporation of little or no seawater-derived sulfide into the rocks. These data are consistent with models for the presence of rock-dominated sulfur in deep hydrothermal fluids. The presence of anhydrite at $1176 \mathrm{~m}$ within basement indicates that unaltered seawater can penetrate to significant depths in the crust during recharge.
\end{abstract}

\section{INTRODUCTION}

Hole 504B is the deepest basement hole in the oceanic crust, and it is the only hole to pass through a pillow section altered at low temperatures $\left(<150^{\circ} \mathrm{C}\right)$ into a hydrothermally altered sheeted dike complex. Prior to Leg 111 of the Ocean Drilling Program (ODP), the hole reached a depth of $1076 \mathrm{~m}$ within basement. In the fall of $1986 \mathrm{Leg} 111$ returned to Hole 504B and extended penetration $212.3 \mathrm{~m}$ farther into the sheeted dikes, to a total depth of $1287.8 \mathrm{~m}$ within basement. In this paper we present the mineralogy, chemistry, and oxygen isotope geochemistry of the hydrothermally altered rocks sampled on Leg 111. Our objective is to extend and test the model for hydrothermal alteration of the crust based on results of previous drilling at the site (e.g., Alt et al., 1986a, 1986b). Preliminary data on sulfide mineralogy and sulfur isotopic compositions of these rocks are also presented in order to provide constraints on the geochemistry of sulfur in submarine hydrothermal systems.

\section{SITE 504 AND PREVIOUS WORK}

Hole 504B is drilled in 5.9-m.y.-old crust in the eastern Pacific (Fig. 1). Beneath $274.5 \mathrm{~m}$ of sediment, coring has penetrated a 571.5-m-thick pillow section, a 209-m-thick transition zone, and $507.5 \mathrm{~m}$ of sheeted dikes (Fig. 2). The lowermost $212.3 \mathrm{~m}$ of the section was cored on Leg 111, with an average recovery rate of about $13 \%$.

The drilled section is divided into three zones, based on the distribution of secondary minerals with depth (Fig. 2). The upper $310 \mathrm{~m}$ of the pillow section is characterized by the presence of centimeter-size reddish oxidation halos around fractures. Fe-

\footnotetext{
' Becker, K., Sakai, H., et al., 1989. Proc. ODP, Sci. Results, 111: College Station, TX (Ocean Drilling Program).

2 Department of Earth and Planetary Sciences, Campus Box 1169, Washing. ton University, St. Louis, MO 63130.

${ }^{3}$ Department of Geology, University of Illinois, Urbana, IL 61801.

4 Department of Geology, University of Alberta, Edmonton, Alberta, Canada T6G 2E3.
}

oxyhydroxides, celadonite, and saponite replace olivine and fill vugs and fractures in the rocks.

In the lower half of the pillow section, saponite replaces olivine and fills vugs and fractures. Traces of chlorite and talc are present, and pyrite is common. Plagioclase is also slightly altered to saponite.

At $624 \mathrm{~m}$ within basement, greenschist facies mineral assemblages appear abruptly in the lithologic transition and are present to the bottom of the core. Clinopyroxene is variably recrystallized to actinolite; olivine is replaced by chlorite, mixed-layer clays, talc, pyrite, and minor actinolite; plagioclase is variably replaced by albite, chlorite, mixed-layer clays, and calcic zeolites; and titanomagnetite is replaced by sphene. Fractures exhibit several episodes of opening and secondary mineral deposition. A stockworklike mineralization, with veins of quartz and sulfides in a 20 -m-thick section of highly altered pillow basalts, is present near the top of the lithologic transition zone (Fig. 2).

Work on the mineralogy, whole-rock chemistry, stable isotope (oxygen, carbon, and sulfur) geochemistry, and fluid inclusions of the section previously drilled in Hole 504B led to the development of a multistage model for the hydrothermal history of the site (Honnorez et al., 1985; Alt et al., 1986a, 1986b). At the spreading axis, stage 1 greenschist facies minerals formed in the dikes and transition zone during reaction with seawater at water/rock ratios of about one and at temperatures of $250^{\circ}-$ $350^{\circ} \mathrm{C}$. Subsequently, stage 2 quartz, epidote, and sulfides formed in fractures at temperatures of $200^{\circ}-350^{\circ} \mathrm{C}$ from more highly reacted hydrothermal fluids ( $\mathrm{Mg}$ depleted, ${ }^{18} \mathrm{O}$ enriched). In contrast, temperatures throughout the pillow section were much lower, less than $150^{\circ} \mathrm{C}$ and as low as $0^{\circ} \mathrm{C}$. Temperatures increased downward by as much as $250^{\circ} \mathrm{C}$ over a 70 -m-thick interval at the top of the transition zone, where greenschist assemblages and ${ }^{18} \mathrm{O}$-depleted rocks appear at $624 \mathrm{~m}$ within basement (Fig. 2). This steep paleotemperature gradient defines the top of a subsurface mixing zone that coincided with the permeability contrast between pillows and dikes during stages 1 and 2 . The stockworklike mineralization formed during stage 2 in this zone, where highly reacted fluids upwelling through the dikes mixed 


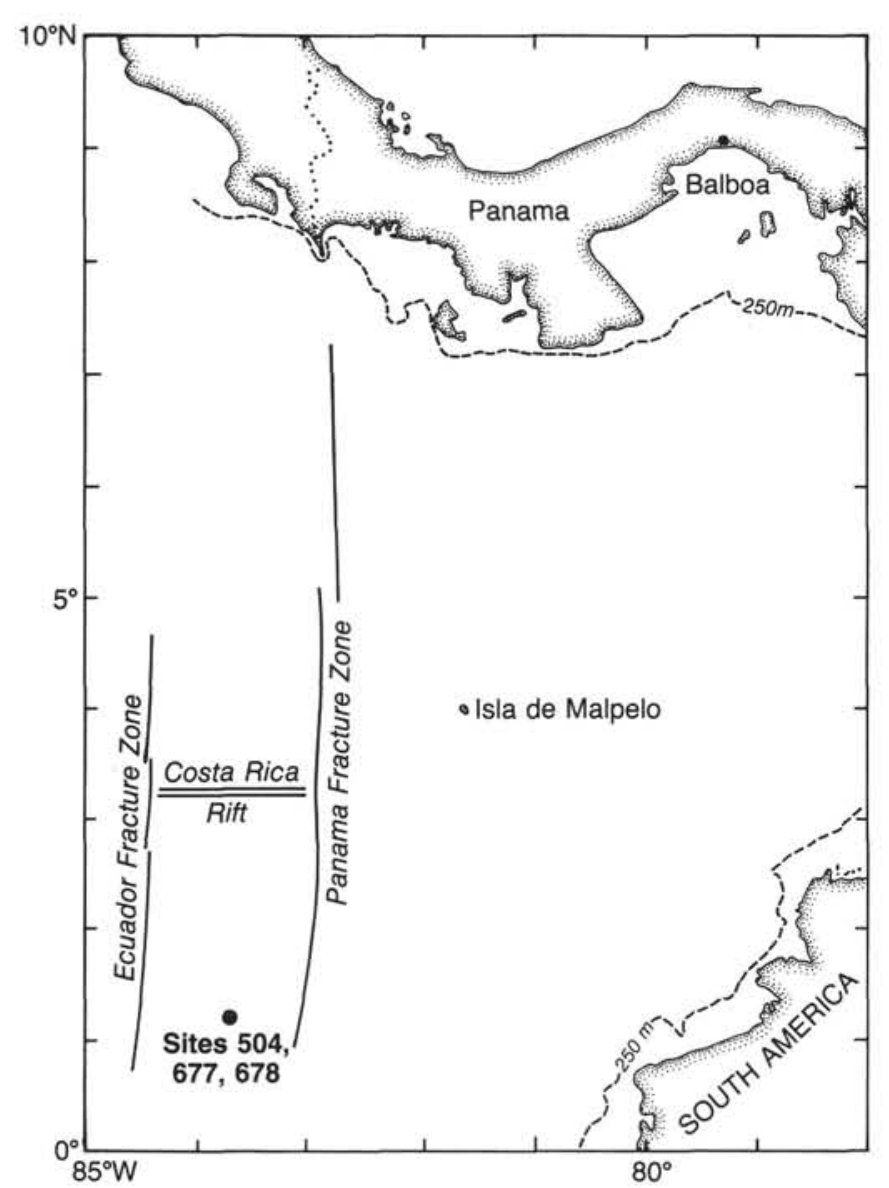

Figure 1. Location of Site 504 in the eastern Pacific.

with cooler seawater circulating in the more highly permeable pillow section.

During stage 3, anhydrite precipitated locally in fractures in the dike section as seawater recharge penetrated into the hot rocks. Subsequent stage 4 off-axis alteration of the transition zone and dikes was characterized by the formation of calcic zeolites, prehnite, and calcite at temperatures of about $100^{\circ}-250^{\circ} \mathrm{C}$ from highly evolved fluids containing mantle-derived $\mathrm{CO}_{2}$. In contrast, later carbonates and zeolites in the pillow section formed at much lower temperatures $\left(0^{\circ}-50^{\circ} \mathrm{C}\right)$ from fluids with a carbon isotopic composition of seawater. Crust at Site 504 eventually was sealed to convective cooling, allowing reheating to the presently observed conductive geothermal gradient. Currently, temperature measurements in the hole range from $60^{\circ} \mathrm{C}$ at the sediment/basement interface, to $135^{\circ} \mathrm{C}$ at the top of the lithologic transition zone, to $180^{\circ} \mathrm{C}$ at the bottom of the hole (Becker et al., 1983).

\section{METHODS}

Minerals were identified by optical examination of polished thin sections in transmitted and reflected light and by X-ray diffraction. Clay minerals were scraped from veins, and the $<2-\mu \mathrm{m}$ fraction was separated from whole rocks. Oriented clay separates mounted on $\mathrm{Ag}$ filters were scanned from $40^{\circ}$ to $2^{\circ} 2 \theta$ with the diffractometer at $1^{\circ} / \mathrm{min}$ following various treatments. Treatments included air drying, saturation with ethylene glycol, and heating at $300^{\circ} \mathrm{C}$ for $2 \mathrm{hr}$. Chemical compositions of secondary minerals were analyzed using a JEOL 733 electron microprobe. Operating conditions were $15-20 \mathrm{kV}$ accelerating voltage, 25-30-nA sample current, $1-\mu \mathrm{m}$ spot size for sulfides and actinolite and a defocused $(10-\mu \mathrm{m})$ spot for clays, and 10- to 30-s counting times.
Rocks for chemical analysis were selected to be representative of the core, including samples of the typical dark gray rock as well as more extensively recrystallized, lighter-colored material and one breccia sample. Major and trace elements were analyzed by X-ray fluorescence. Errors determined by repeated analysis of samples and standards are $<2 \%$ of reported values for $\mathrm{Si}, \mathrm{Al}, \mathrm{Mg}, \mathrm{Fe}, \mathrm{Ti}, \mathrm{Ca}, \mathrm{Mn}$, and $\mathrm{K}$ and $<10 \%$ for Na. Errors for $P$ and trace elements are $\pm 0.01 \%$ and $\pm 10 \mathrm{ppm}$, respectively. Densities of rock fragments determined after drying at $100^{\circ} \mathrm{C}$ were reproducible within $1 \%$.

Minerals were separated from veins by hand picking and chemical techniques (Syers et al., 1968) for isotopic analysis. Oxygen was extracted from whole-rock powders and mineral separates using the $\mathrm{BrF}_{5}$ method (Clayton and Mayeda, 1963), and mass spectrometer measurements of oxygen isotope ratios are reported as the standard $\delta$ notation relative to SMOW (standard mean ocean water; Craig, 1961).

Various forms of sulfur were extracted from whole-rock powders for isotopic analysis using a stepwise technique modified from Puchelt and Hubberten (1979). In the first step, monosulfides (such as pyrrhotite, chalcopyrite, pentlandite, etc.) were decomposed by reaction with $5 \mathrm{~N}$ $\mathrm{HCl}$ at $80^{\circ} \mathrm{C}$ for at least $1 \mathrm{hr}$ in a closed vessel, through which nitrogen was circulated continuously. $\mathrm{Zn}$ metal was added in order to reduce cuprous sulfides (Ueda and Sakai, 1983). Evolved $\mathrm{H}_{2} \mathrm{~S}$ was precipitated as $\mathrm{Ag}_{2} \mathrm{~S}$ by bubbling the carrier gas through an $\mathrm{AgNO}_{3}$ solution. The $\mathrm{HCl}$ solution was filtered and $\mathrm{BaCl}_{2}$ solution added to precipitate as $\mathrm{BaSO}_{4}$ any soluble sulfate extracted from the rock. Pyrite sulfur was extracted from the residue of the previous step by reaction with a $\mathrm{CrCl}_{2}-\mathrm{HCl}$ solution at $80^{\circ} \mathrm{C}$ in a stream of nitrogen (Canfield et al., 1986), and evolved $\mathrm{H}_{2} \mathrm{~S}$ was precipitated as $\mathrm{Ag}_{2} \mathrm{~S}$.

Sulfur isotope ratios were measured with the mass spectrometer on $\mathrm{SO}_{2}$ gas, which was produced from $\mathrm{Ag}_{2} \mathrm{~S}$ by combustion with $\mathrm{Cu}_{2} \mathrm{O}$ under vacuum at $950^{\circ} \mathrm{C}$ and from $\mathrm{BaSO}_{4}$ by combustion with sodium metaphosphate under vacuum at $950^{\circ} \mathrm{C}$. Data are reported as $\delta$ notation relative to Canyon Diablo Troilite (CDT).

\section{RESULTS AND DISCUSSION}

\section{Alteration of Silicates}

Alteration of silicates in the dikes recovered during Leg 111 is essentially the same as in the previously described dike section recovered on Deep Sea Drilling Project (DSDP) Leg 83 (Alt et al., 1985, 1986a). Important differences exist, however, in the extent of alteration of clinopyroxene and plagioclase and in the relative proportions of secondary actinolite and albite. In the upper (Leg 83) dike section the main alteration effects are replacement of olivine by chlorite $( \pm$ mixed-layer clays, talc, and actinolite) and of plagioclase by albite; clinopyroxene is generally only partly altered to actinolite. In contrast, in the Leg 111 dikes clinopyroxene is more extensively altered to actinolite, whereas plagioclase is less extensively altered to albite. Actinolite is also more common replacing olivine in the Leg 111 samples. These effects may be the result of somewhat greater temperatures of alteration toward the base of the drilled dike section, possibly approaching the stability of more calcic plagioclase (Liou et al., 1974).

The sequence of formation of secondary minerals in veins and fractures is generally similar to that observed in the Leg 83 rocks: (1) chlorite + actinolite \pm sphene \pm pyrite; (2) quartz \pm actinolite \pm pyrite \pm rare epidote \pm chlorite; and (3) zeolites (laumontite) + prehnite. In general, fewer and narrower veins of quartz and zeolites are present in the Leg 111 rocks than in the Leg 83 dikes. This difference may be due to drilling difficulties and poor recovery on Leg 111 , however. The sequence of secondary mineral formation is consistent with the previously proposed model for the hydrothermal history of the site (Alt et al., 1986a).

The rocks are generally dark gray in color and only partly recrystallized $(<50 \%)$. More extensive alteration occurs locally, however. Lighter colored areas, a few centimeters in size, correspond to the more extensively recrystallized parts of the rock 


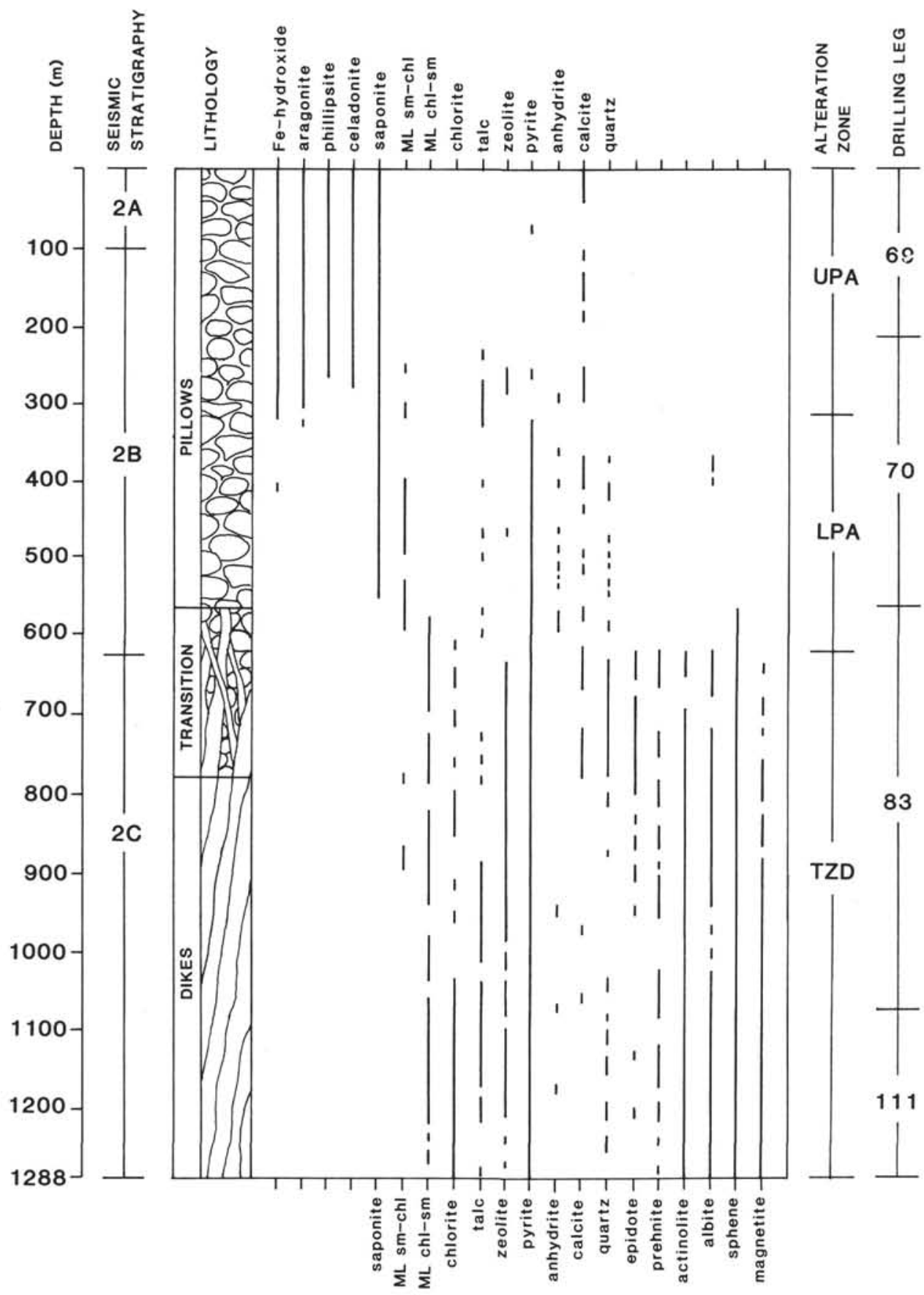

Figure 2. Lithostratigraphy and distribution of secondary minerals within basement in Hole 504B (modified from Alt et al., 1986a). The section drilled during Leg 111 extends from 1076 to $1288 \mathrm{~m}$ within basement. ML sm-chl = smectite-rich mixed-layer clays; $\mathrm{ML} \mathrm{chl-sm} \mathrm{=} \mathrm{chlorite-rich} \mathrm{mixed-layer} \mathrm{clays} \mathrm{(see}$ text).

which had originally higher porosity than the host rocks. At $1163 \mathrm{~m}$ within basement, the rocks are nearly completely recrystallized to coarse actinolite, albite, and sphene, and extensively altered rocks containing abundant laumontite are at $1239 \mathrm{~m}$ within basement. Similar heterogeneous effects have been observed in Leg 83 samples (Alt et al., 1985).

Secondary minerals are generally similar in composition to those from the Leg 83 dike section. Chlorites in Leg 111 rocks are similar in composition to those from the Leg 83 section, mostly falling within the pycnochlorite field (Fig. 3). Minor amounts of expandable layers (smectite or vermiculite) are present in some chlorite samples, as indicated by slight expansion of 001 spacings after glycolation.

Mixed layering of chlorite-expandable clay (smectite and vermiculite) is present in many samples, as indicated by the presence of basal spacings at $15.5-16.8 \AA$ after glycolation. The mixed-layer clays contain greater amounts of $\mathrm{Si}$ and $\mathrm{Mg}$ and less $\mathrm{Fe}$ and $\mathrm{Al}$ than the chlorites (Fig. 3). Similar structural and compositional variations among chlorites occur in the Leg 83 section (Alt et al., 1985). 


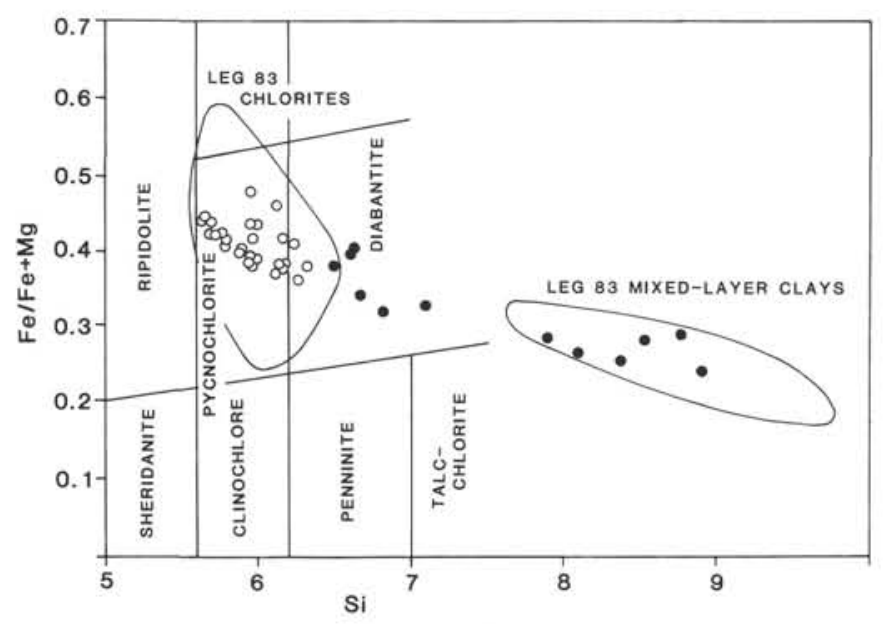

Figure 3. Molar compositions of Leg 111 chlorites (open circles) and mixed-layer chlorite-expandable clays (solid circles). Fields of chlorites and mixed-layer clays from Leg 83 rocks are shown for comparison (from Alt et al., 1985).

Microprobe analyses of talc generally indicate small amounts of $\mathrm{Fe}, \mathrm{Al}$, and $\mathrm{Ca}$, suggesting that some smectite or mixed-layer smectite-chlorite material is also present.

Amphiboles range in composition from actinolite to ferroactinolite, actinolitic hornblende, and into the magnesiohornblende fields (Fig. 4). This variation is similar to that observed in amphiboles from the Leg 83 dikes.

\section{Sulfide, Sulfate, and Oxide Mineralogy}

Recrystallized igneous sulfides are common. Most consist of $<40-\mu$ m-diameter round globules or irregularly-shaped grains of chalcopyrite \pm pyrite \pm magnetite \pm intermediate solidsolution $\mathrm{Cu}-\mathrm{Fe}$ sulfide \pm pyrrhotite in interstitial areas, with secondary chlorite, actinolite, and sphene. Small amounts of hematite were also observed in a few samples. Recrystallized igneous sulfides are common in plagioclase phenocrysts and segregated late-stage quartz + albite + apatite, which are produced by extensive $(>90 \%)$ crystallization of basaltic liquid (Sinton and Byerly, 1979). Pyrrhotite is most common in plagioclase phenocrysts and late-stage segregated quartz (Fig. 5D). Pyrrhotites contain variable amounts of $\mathrm{Ni}(0.5 \%-2.5 \%)$ and traces of Co $(0 \%-0.27 \%)$, but have relatively constant mole fractions of FeS $(0.92 \pm 0.01)$.

\section{Pyrite}

Pyrite is the most abundant sulfide mineral throughout the section. Its most common occurrence is as large (up to several hundred microns), porous crystals replacing silicates (Fig. 5A), particularly in clay mineral pseudomorphs of olivine pheno-

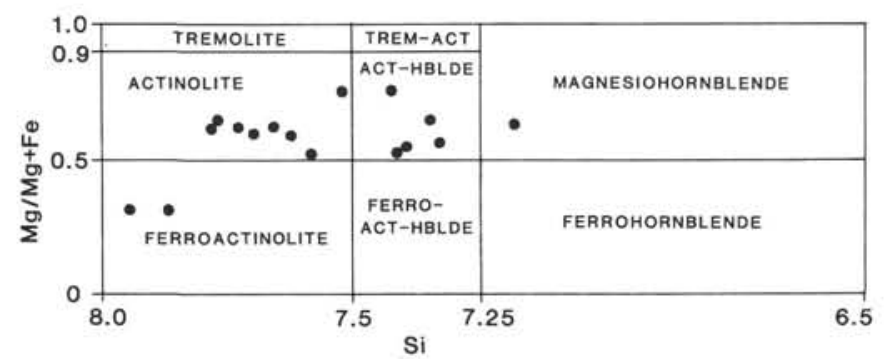

Figure 4. Molar compositions of amphiboles in Leg 111 rocks. crysts. Chalcopyrite is commonly intergrown with pyrite, which typically contains inclusions of chalcopyrite and rarely pyrrhotite. Pyrite also occurs in early chlorite + actinolite veins and in later quartz veins in Core 111-504B-145R at $1105 \mathrm{~m}$ within basement.

Nonsystematic variations in $\mathrm{Co}$ and $\mathrm{Ni}$ contents occur within individual grains and among grains in a single thin section. Co content is generally $>0.3 \%$, but values up to $10.9 \%$ occur in pyrite in a vein with chalcopyrite and magnetite at $1105 \mathrm{~m}$ within basement. Ni content ranges up to $3.5 \%$, but is generally less than $0.3 \%$. Some of the high Ni contents may be the result of small inclusions of millerite (NiS).

\section{$\mathrm{Cu}$-Fe Sulfides}

Chalcopyrite is the second most abundant sulfide mineral. It occurs as round and irregular grains, generally $<40 \mu \mathrm{m}$ but up to hundreds of microns in size, in interstitial areas and altered phenocrysts. Some of the smaller grains are probably recrystallized igneous sulfides, but many are of secondary origin. These clearly replace silicates or are intergrown with pyrite. Chalcopyrite occurs in chlorite + quartz veins in Core 111-504B-145R. Within analytical errors ( $<1 \%$ of reported values), chalcopyrites have stoichiometric compositions. Rare intermediate solidsolution $\mathrm{Cu}$-Fe sulfides were identified associated with pyrrhotite in late quartz segregates, however. These are probably relict igneous sulfides.

Bornite was identified in three samples from the lowermost $150 \mathrm{~m}$ of core. In one sample (111-504B-163R-2, 105-107 cm) bornite occurs as irregular, small (4-6- $\mu \mathrm{m})$ grains in actinolite replacing clinopyroxene. Similar-size grains of magnetite, chalcopyrite, and pyrite are also present. In Samples 111-504B-154R-1, $109-113 \mathrm{~cm}$, and 111-504B-169R-1, 121-125 cm, 5- $\mu$ m-diameter igneous sulfides in fresh and altered plagioclase phenocrysts are recrystallized to bornite \pm chalcopyrite. Microprobe analyses indicate compositions close to stoichiometric bornite $\left(\mathrm{Cu}_{5} \mathrm{FeS}_{4}\right)$.

\section{Millerite}

Millerite (NiS) was identified in one sample from Leg 111, but was also observed in samples from the Leg 83 section. In Sample 111-504B-144R-1 (Piece 1), 10-20- $\mu \mathrm{m}$ grains of millerite are intergrown with larger porous pyrite \pm chalcopyrite replacing silicates and enclosed in quartz (Fig. 5B). Microprobe analyses indicate traces of $\mathrm{Fe}$ and $\mathrm{Co}(0.8$ and $0.2 \mathrm{wt} \%$, respectively) in the millerite.

\section{Other Sulfide Phases}

One grain of Ni-rich carrollite $\left(\mathrm{CuCO}_{2} \mathrm{~S}_{4}\right)$ was identified in a sample from the Leg 83 section, and linnaeite $\left(\mathrm{CO}_{3} \mathrm{~S}_{4}\right)$ was identified in the Leg 111 section (P. Herzig, pers. comm., 1988). Trace amounts of a bluish gray, isotropic Fe-sulfide phase occur in recrystallized igneous sulfide globules in the Leg 111 rocks. Qualitative energy-dispersive X-ray analyses indicate an Fe-sulfide composition, but the phase remains unidentified.

\section{Secondary Iron Oxides}

Secondary iron oxides are ubiquitous in varying amounts throughout the dike section. They are most common in altered pyroxenes and olivines, but are also present locally in veins.

By far the most common occurrence of secondary oxides is as small (up to several microns) blebs of magnetite in actinolite replacing clinopyroxene and in partly altered or "corroded" clinopyroxene (Fig. 6A). Some similar micron-size grains of pyrite, chalcopyrite, and hematite are also present in altered pyroxenes.

Phyllosilicate (chlorite, mixed-layer clays, and talc) pseudomorphs of olivine phenocrysts occur throughout the dike section and commonly contain $1-20-\mu \mathrm{m}$ irregular blebs of magne- 


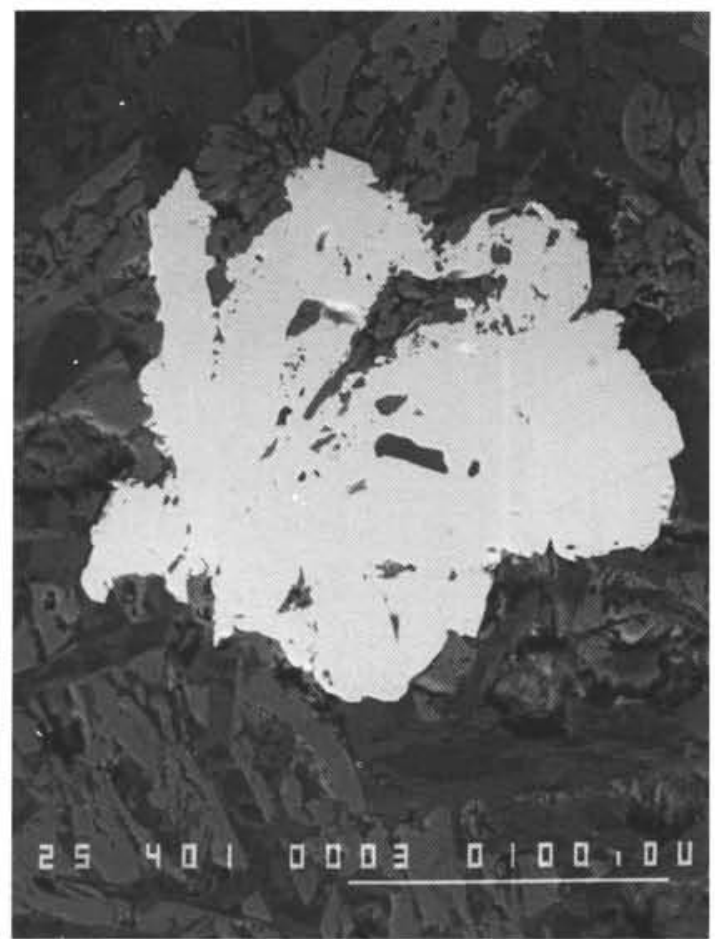

A

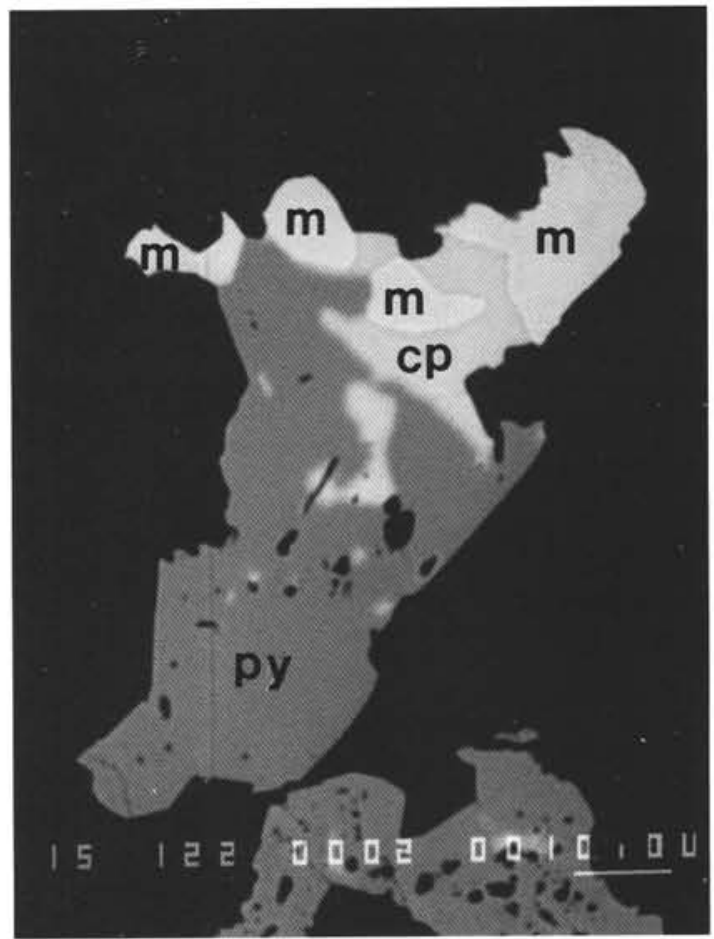

B

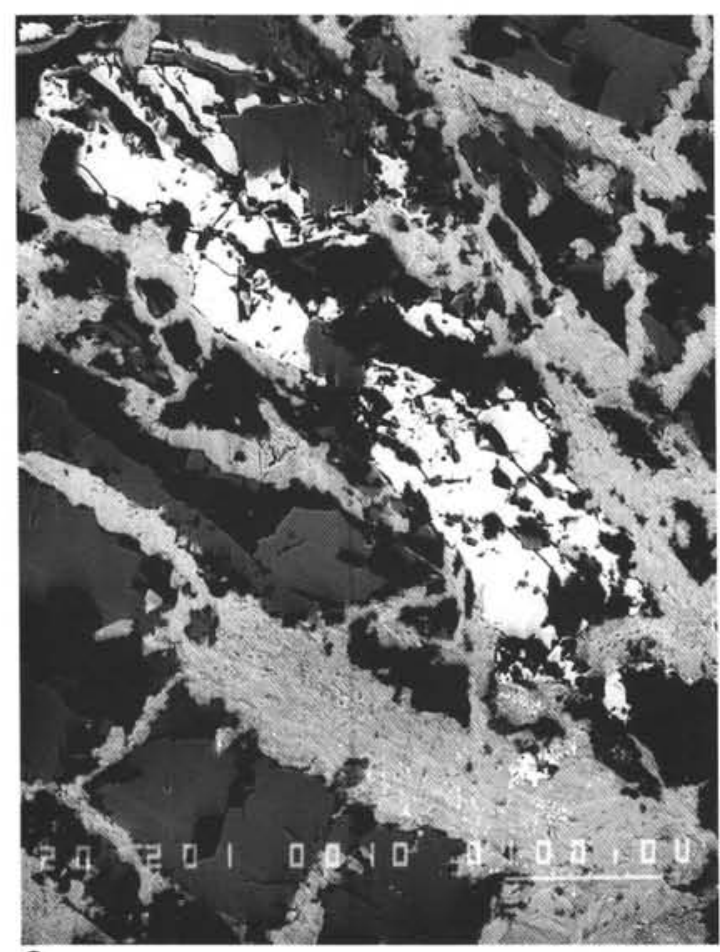

C

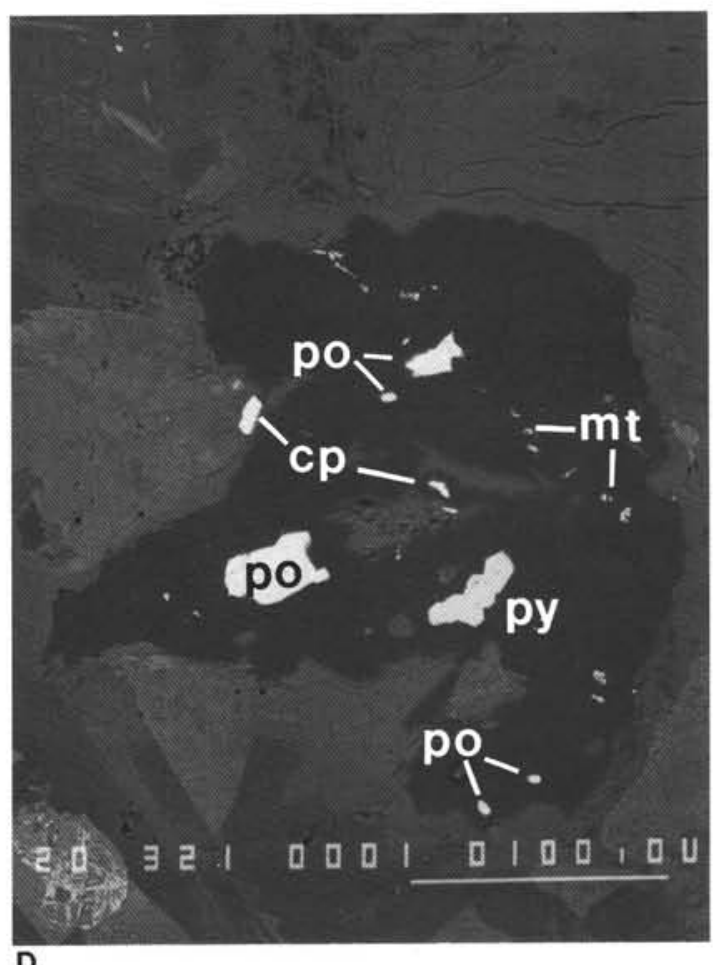

D

Figure 5. Back-scattered electron photomicrographs of sulfides and anhydrite in Leg 111 rocks. A. Typical pyrite replacing silicates. Scale $=100 \mu \mathrm{m}$. B. Millerite $(\mathrm{m})$ with pyrite $(\mathrm{py})$ and chalcopyrite $(\mathrm{cp})$ in a silicate and quartz matrix (black). Pyrite contains inclusions of chalcopyrite. Scale $=10 \mu \mathrm{m}$. Sample 111-504B144R-1, 0-5 cm. C. Anhydrite (white) replacing plagioclase (dark gray). Lighter gray areas are actinolite + magnetite (white spots) pseudomorphs after clinopyroxene. Scale $=100 \mu \mathrm{m}$. Sample 111-504B-152R-1, 19-25 cm. D. Pyrrhotite (po), pyrite (py), chalcopyrite (cp), and magnetite (mt) surrounded by quartz (dark gray). Scale $=100 \mu \mathrm{m}$. Sample 111504B-159R-1, 10-12). 


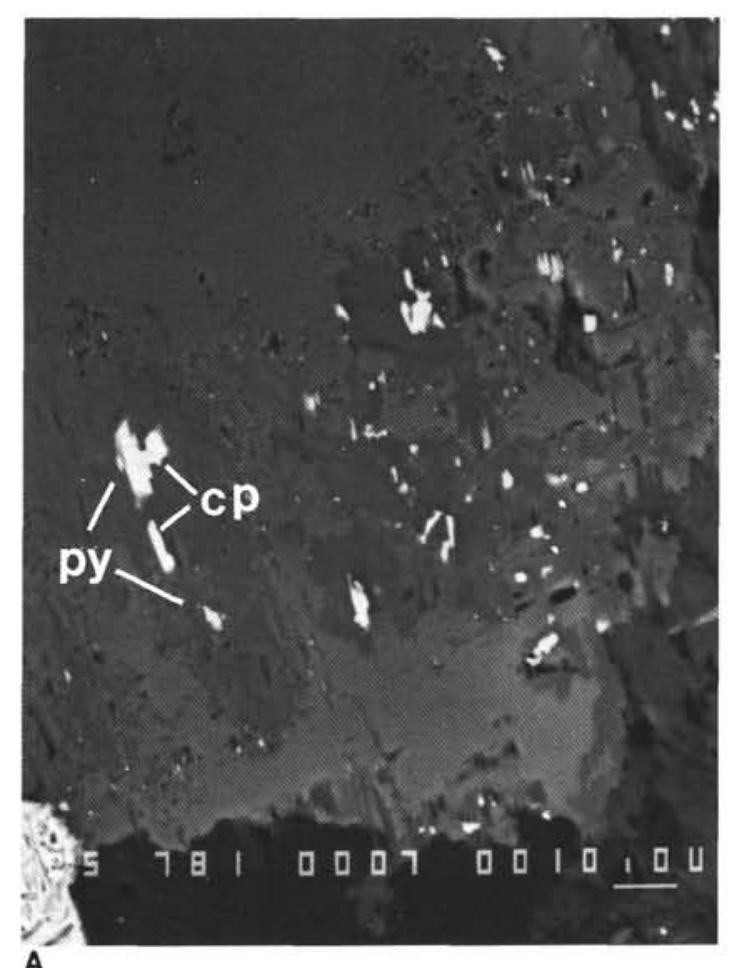

A

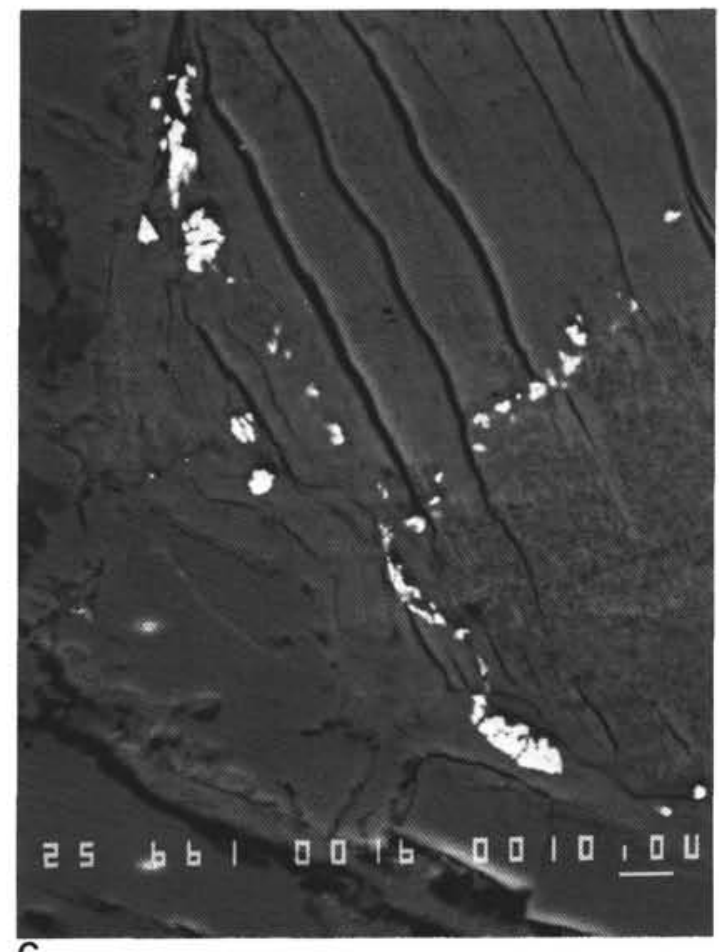

C

Figure 6. Back-scattered electron photomicrographs of secondary magnetite in Leg 111 rocks. A. Clinopyroxene (gray) partly replaced by actinolite (darker gray patches and lower right), with small grains of magnetite (white), pyrite (py), and chalcopyrite (cp). Scale $=10 \mu \mathrm{m}$. Sample 111-504B-163R-1, 115-118 cm. B. Magnetite (white) and chalcopyrite (cp) in mixed-layer chlorite-smectite pseudomorph of olivine phenocryst. Also present are small actinolite needles in the right half of the pseudomorph and a larger actinolite crystal (act) at the top. Scale $=100 \mu \mathrm{m}$. Sample 111-504B-150R-1, 138-140 cm. C. Detail of secondary magnetite from the left side of Figure 6B. Scale = $10 \mu \mathrm{m}$. D. Magnetite (dark gray) and chalcopyrite (light gray) in vein with quartz (black). Scale $=100 \mu \mathrm{m}$. Sample 111-504B-145R-1, $40-42 \mathrm{~cm}$.
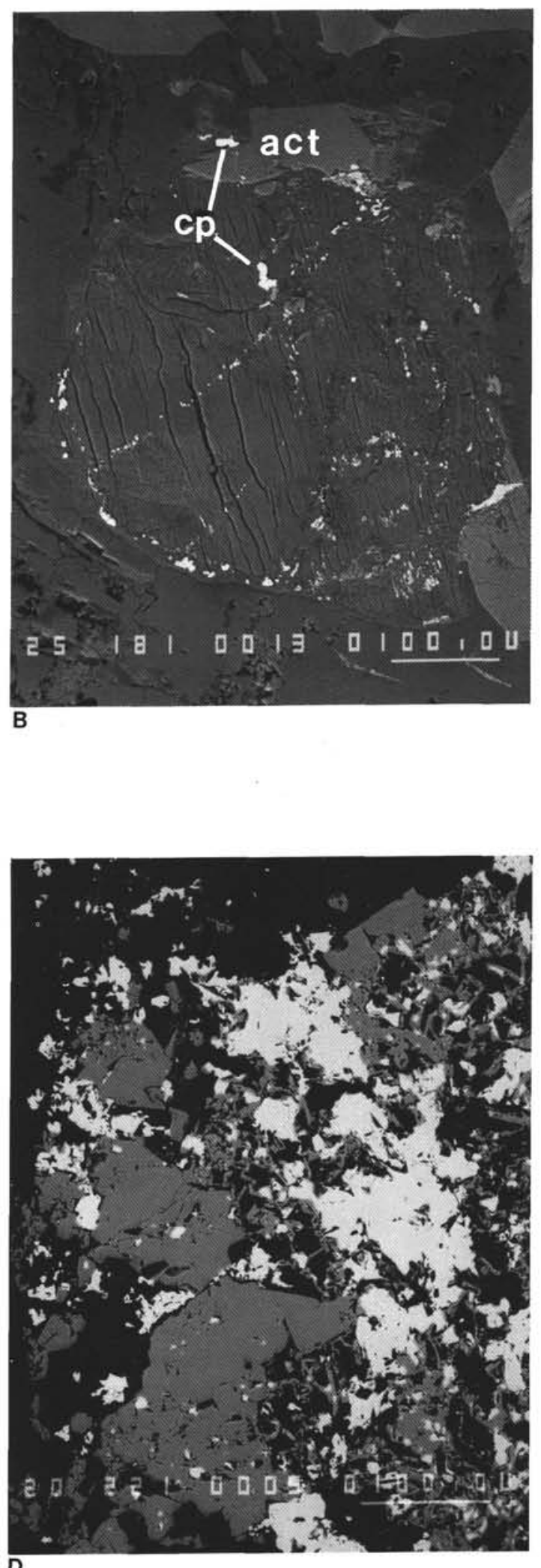

D 
tite, some of which are arranged in concentric or linear bands (Figs. 6A and 6B). Similar-size grains of pyrite and chalcopyrite are common, some of which are intergrown with the magnetite. Larger porous pyrite grains, up to $1 \mathrm{~mm}$ in size, are common and sporadically enclose secondary magnetite. Hematite is locally present as $1-10-\mu \mathrm{m}$ blebs in linear arrays and associated with the magnetite.

Secondary magnetite rarely occurs in veins. Porous aggregates, up to a few hundred microns in size, of micron-size blebs of magnetite occur in chlorite veins at 1105 and $1191 \mathrm{~m}$ within basement. Similar-size aggregates of irregular magnetite are intergrown with pyrite and chalcopyrite in chlorite + quartz veins in Core 111-504B-145R (Fig. 6D).

Ilmenite occurs as laths and granular aggregates with magnetite in chlorite and quartz veins at 1081 and $1191 \mathrm{~m}$ within basement. These forms appear to be secondary, but may be recrystallized igneous titanomagnetite and ilmenite from the adjacent wall rock.

\section{Anhydrite}

Anhydrite occurs locally as a relatively late mineral in veins of the Leg 83 dike section (Alt et al., 1985). In the Leg 111 section, anhydrite was found on a chlorite-lined fracture surface at $1176 \mathrm{~m}$ with basement (Sample 111-504B-153R-1, 60-62 cm). In extensively recrystallized, coarse-grained rocks at $1163 \mathrm{~m}$ within basement, plagioclase is partly replaced by anhydrite (Fig. 5C).

\section{Sulfide-Oxide Phase Equilibria}

The simplest interpretation of sulfide mineral phase equilibria involves formation of sulfide and oxide minerals during axial hydrothermal alteration, followed by partial recrystallization of minerals at lower temperatures and the formation of new phases.

Alteration temperatures in the dikes during stage 1 were about $250^{\circ}-350^{\circ} \mathrm{C}$ (Alt et al., 1986a, 1986b). The assemblage pyrite + chalcopyrite + magnetite, which is the most common in the rocks, is stable at these temperatures. The presence of pyrrhotite inclusions in pyrite suggests that pyrrhotite was also stable. Thus, it appears that the stable sulfide-oxide mineral assemblage was pyrite + magnetite + chalcopyrite + pyrrhotite (Fig. 7).

Various lines of evidence indicate subsequent partial recrystallization of sulfides in Hole 504B at lower temperatures. The observed millerite + pyrite assemblages are stable only at temperatures less than $200^{\circ} \mathrm{C}$ (Craig, 1973). Gitlin (1985) showed that sulfur-rich compositions of pyrrhotites, like those in the Hole 504B dikes, indicate re-equilibration at temperatures less than $150^{\circ} \mathrm{C}$. The stability fields of pyrite, bornite, and hematite expand to lower oxygen and sulfur fugacities with decreasing temperatures (Fig. 7). Thus, with decreasing temperatures (and little or no change in oxygen and sulfur fugacities) pyrrhotite would be replaced by pyrite, hematite would replace magnetite, and chalcopyrite would recrystallize to bornite, which are consistent with the observed mineral relationships. Present temperatures at Site 504 range from $135^{\circ} \mathrm{C}$ at the top of the lithologic transition to $180^{\circ} \mathrm{C}$ at the bottom of the hole (Becker et al., 1983). Depending upon when the crust was sealed to convective cooling, such temperatures could have existed for $10^{3}$ to $10^{6} \mathrm{yr}$, ample time for the sulfides to re-equilibrate (Barton and Skinner, 1979).

\section{Whole-Rock Geochemistry}

The average composition of unaltered glass from the pillow section (Table 1) is used as a basis for comparison with the altered dikes from Hole 504B. Altered-rock analyses have been recalculated $\mathrm{H}_{2} \mathrm{O}$-free and normalized to constant volume. This affects the magnitudes of elemental changes in the Leg 111 sam-

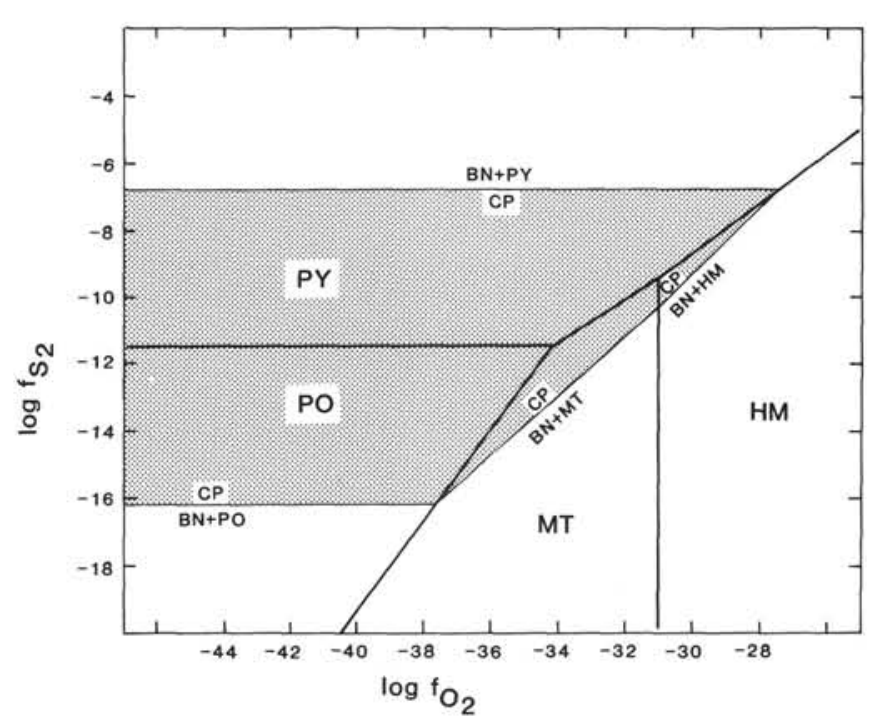

Figure 7. Oxygen-sulfur fugacity diagram showing stability fields of pyrite (PY), pyrrhotite (PO), magnetite (MT), and hematite (HM) at $300^{\circ} \mathrm{C}$ and 500 bar. The shaded area shows the stability field of chalcopyrite $(\mathrm{CP})$ bounded by bornite $(\mathrm{BN})$ plus another sulfide or oxide (modified from Brimhall, 1980).

ples, but does not alter the general direction of chemical changes with respect to glass. The following discussion is thus based on direct comparison of the compositions of altered rock and average glass listed in Table 1.

The chemical analyses of Leg 111 dikes given in Table 1 are plotted in Figure 8 along with other data for Hole 504B. The Leg 111 data are quite similar to those for the Leg 83 dike section, with generally slight chemical changes as the result of hydrothermal alteration. The trends toward gain of $\mathrm{Na}$ and loss of $\mathrm{Ca}$ because of albitization are somewhat less apparent in the Leg 111 samples than in the Leg 83 rocks. There is a slight enrichment of $\mathrm{Mg}$ in several samples from 1076 to $1163 \mathrm{~m}$ within basement, but most samples exhibit no gain in $\mathrm{Mg}$. Experimental data predict that $\mathrm{Mg}$ fixation by the crust is a major chemical effect of hydrothermal alteration by seawater (Mottl, 1983). The general absence of $\mathrm{Mg}$ enrichment in the Leg 83 rocks was attributed to fixation of $\mathrm{Mg}$ in clay minerals filling fractures and cementing breccias, rather than in the altered rocks themselves (Alt et al., 1985, 1986a). The results of geochemical logging during Leg 111 suggest that such breccias were commonly not recovered during drilling (Anderson et al., this volume).

Other general features of the Leg 111 section are increases in $\mathrm{H}_{2} \mathrm{O}$ contents, decreases in densities, slight increases in $\mathrm{Fe}^{3+} / \mathrm{Fe}^{\mathrm{T}}$ (unaltered glass $\mathrm{Fe}^{3+} / \mathrm{Fe}^{T}=0.12$; Puchelt and Emmermann, 1983), and very low K contents as a result of leaching by hydrothermal fluids. Copper is slightly enriched at about 1090-1160 m within basement, but the systematic differences in $\mathrm{Co}, \mathrm{Sr}$, and $\mathrm{CO}_{2}$ relative to the Leg 83 section are probably caused by analytical differences.

Chemical effects are locally heterogenous, reflecting differences in permeability and hence the extent of water-rock interaction, as well as varying solution compositions through time. The more extensively recrystallized greenish patches of Sample 111-504B-147R-2, 6-10 cm, have gained $\mathrm{Na}, \mathrm{Mg}$, and $\mathrm{H}_{2} \mathrm{O}$ and lost $\mathrm{Ca}, \mathrm{Ti}$, and $\mathrm{Fe}$ relative to the adjacent dark gray host rock. The recrystallized patches originally contained greater amounts of pore space, which enabled more extensive interaction with hydrothermal fluids. Sample 111-504B-143R-1, 128-135 cm, however, exhibits only slight chemical variations between the different textural zones. 
Table 1. Whole-rock chemical analyses of rocks recovered on Leg 111 from Hole 504B.

\begin{tabular}{|c|c|c|c|c|c|c|c|c|c|c|c|}
\hline & \multicolumn{11}{|c|}{ Core, section, interval $(\mathrm{cm})^{\mathrm{a}}$} \\
\hline & $\begin{array}{c}142 \mathrm{R}-1 \\
112-117 \\
\text { (breccia) }\end{array}$ & $\begin{array}{c}142 R-2 \\
5-8\end{array}$ & $\begin{array}{c}143 \mathrm{R}-1 \\
128-135 \\
\text { (dark) }\end{array}$ & $\begin{array}{c}143 R-1 \\
128-135 \\
\text { (light) }\end{array}$ & $\begin{array}{c}145 R-1 \\
40-42\end{array}$ & $\begin{array}{c}146 R-1 \\
21-24\end{array}$ & $\begin{array}{c}147 \mathrm{R}-2 \\
6-10 \\
\text { (dark) }\end{array}$ & $\begin{array}{c}147 R-2 \\
6-10 \\
\text { (light) }\end{array}$ & $\begin{array}{c}148 \mathrm{R}-1 \\
115-118\end{array}$ & $\begin{array}{c}150 \mathrm{R}-1 \\
138-140\end{array}$ & $\begin{array}{c}152 R-1 \\
19-25\end{array}$ \\
\hline $\mathrm{SiO}_{2}(\mathrm{wt} \%)$ & 48.20 & 49.20 & 48.00 & 48.10 & 48.60 & 49.10 & 49.40 & 50.20 & 50.00 & 49.40 & 42.60 \\
\hline $\mathrm{Al}_{2} \mathrm{O}_{3}(\mathrm{wt} \%)$ & 14.00 & 14.90 & 15.80 & 15.70 & 14.90 & 14.80 & 15.50 & 14.90 & 13.90 & 15.20 & 15.70 \\
\hline $\mathrm{MgO}(\mathrm{wt} \%)$ & 8.07 & 8.35 & 9.17 & 9.42 & 9.94 & 8.33 & 8.67 & 9.44 & 8.17 & 8.74 & 9.89 \\
\hline $\mathrm{FeO}(w \mathrm{t} \%)$ & 7.80 & 7.10 & 6.50 & 6.60 & 6.30 & 7.20 & 6.00 & 6.10 & 7.80 & 6.20 & 10.50 \\
\hline $\mathrm{Fe}_{2} \mathrm{O}_{3}(\mathrm{wt} \%)$ & 3.13 & 2.31 & 2.41 & 2.10 & 2.90 & 2.70 & 2.72 & 1.99 & 2.93 & 2.87 & 5.33 \\
\hline $\mathrm{MnO}(\mathrm{wt} \%)$ & 0.18 & 0.18 & 0.16 & 0.16 & 0.16 & 0.16 & 0.18 & 0.15 & 0.19 & 0.17 & 0.15 \\
\hline $\mathrm{CaO}(\mathrm{wt} \%)$ & 10.30 & 13.10 & 13.20 & 13.00 & 13.20 & 13.10 & 13.20 & 11.70 & 12.30 & 13.10 & 6.74 \\
\hline $\mathrm{Na}_{2} \mathrm{O}(\mathrm{wt} \%)$ & 1.77 & 2.05 & 1.56 & 1.52 & 1.40 & 1.60 & 1.84 & 2.48 & 1.85 & 1.83 & 1.85 \\
\hline $\mathrm{K}_{2} \mathrm{O}(\mathrm{wt} \%)$ & 0.03 & 0.02 & 0.01 & 0.01 & 0.01 & 0.01 & 0.02 & 0.01 & 0.01 & 0.01 & 0.02 \\
\hline $\mathrm{TiO}_{2}(\mathrm{wt} \%)$ & 0.90 & 0.91 & 0.80 & 0.75 & 0.83 & 0.95 & 0.87 & 0.64 & 1.08 & 0.89 & 0.68 \\
\hline $\mathrm{P}_{2} \mathrm{O}_{5}(\mathrm{wt} \%)$ & 0.07 & 0.07 & 0.06 & 0.06 & 0.06 & 0.07 & 0.06 & 0.05 & 0.08 & 0.07 & 0.05 \\
\hline $\mathrm{H}_{2} \mathrm{O}^{+}$(wt $\left.\%\right)$ & 4.80 & 1.80 & 1.80 & 2.00 & 1.60 & 1.40 & 1.20 & 2.20 & 1.40 & 1.30 & 4.90 \\
\hline \multirow[t]{2}{*}{$\mathrm{CO}_{2}(\mathrm{wt} \%)$} & 0.03 & 0.01 & 0.01 & 0.01 & 0.02 & 0.01 & 0.03 & 0.01 & 0.01 & 0.01 & 0.01 \\
\hline & 99.28 & 100.00 & 99.48 & 99.43 & 99.92 & 99.45 & 99.67 & 99.87 & 99.72 & 99.79 & 98.42 \\
\hline Loss on ignition & 5.08 & 1.54 & 1.70 & 2.00 & 1.47 & 1.23 & 1.16 & 2.00 & 1.08 & 1.16 & 5.62 \\
\hline $\mathrm{Fe}_{2} \mathrm{O}_{3}^{\mathrm{T}}$ & 11.80 & 10.20 & 9.63 & 9.43 & 9.90 & 10.70 & 9.39 & 8.77 & 11.60 & 9.76 & 17.00 \\
\hline Co (ppm) & 60 & 60 & 50 & 60 & 50 & 60 & 50 & 50 & 60 & 50 & 80 \\
\hline $\mathrm{Cu}(\mathrm{ppm})$ & 90 & 80 & 140 & 150 & 160 & 100 & 110 & 120 & 80 & 110 & 140 \\
\hline $\mathrm{Ni}(\mathrm{ppm})$ & 40 & 90 & 130 & 110 & 150 & 120 & 160 & 100 & 90 & 110 & 30 \\
\hline $\mathrm{Zn}(\mathrm{ppm})$ & 80 & 60 & 70 & 70 & 60 & 60 & 70 & 60 & 70 & 70 & 80 \\
\hline Mo (ppm) & - & - & - & - & - & - & - & - & - & - & - \\
\hline $\mathrm{Pb}$ (ppm) & 10 & - & - & - & - & - & - & - & - & - & 13 \\
\hline Th (ppm) & - & - & - & - & - & - & - & - & - & - & - \\
\hline $\mathrm{U}(\mathrm{ppm})$ & 20 & 10 & 10 & 10 & 10 & - & 20 & - & - & - & 10 \\
\hline $\mathrm{Cr}(\mathrm{ppm})$ & 210 & 160 & 320 & 320 & 470 & 260 & 370 & 380 & 110 & 370 & 390 \\
\hline $\mathrm{Rb}(\mathrm{ppm})$ & 10 & 10 & 10 & 20 & 10 & 20 & 10 & 10 & - & - & 10 \\
\hline $\mathrm{Sr}(\mathrm{ppm})$ & 10 & 40 & 40 & 40 & 30 & 30 & 40 & 80 & 30 & 30 & 20 \\
\hline $\mathrm{Y}(\mathrm{ppm})$ & 20 & 20 & 20 & 10 & 10 & 20 & 10 & 30 & 10 & 10 & 10 \\
\hline $\mathrm{Zr}(\mathrm{ppm})$ & 40 & 20 & 20 & 20 & 20 & 30 & 30 & 20 & 30 & 40 & - \\
\hline $\mathrm{Nb}(\mathrm{ppm})$ & 20 & 20 & 20 & 10 & 20 & 20 & 10 & - & 20 & - & 10 \\
\hline $\mathrm{Ba}(\mathrm{ppm})$ & - & 10 & 10 & 20 & 20 & 20 & 10 & 10 & 10 & 10 & 50 \\
\hline Depth within basement (m) & 1081.5 & 1082.6 & 1090.6 & 1090.6 & 1104.6 & 1122.8 & 1128.6 & 1128.6 & 1137.5 & 1155.6 & 1162.8 \\
\hline $\mathrm{Fe}^{3+} / \mathrm{Fe}^{\mathrm{T}}$ & 0.266 & 0.227 & 0.250 & 0.222 & 0.293 & 0.252 & $2 \quad 0.290$ & 0.227 & 0.253 & 0.294 & 0.314 \\
\hline Density $\left(\mathrm{g} / \mathrm{cm}^{3}\right)$ & 2.75 & 2.88 & 2.95 & 2.94 & 2.97 & 2.99 & 2.98 & 2.89 & 3.00 & 2.94 & 2.85 \\
\hline
\end{tabular}

Note: Blank $=$ not analyzed; dash $=$ below detection limit.

${ }^{a}$ Light gray alteration halos and dark gray host rocks are labeled where adjacent zones were analyzed. Other samples represent typical dark gray material.

b Composition from Alt et al. (1986a).

c Interlaboratory standard for Leg 111 .

A dike sample from $1163 \mathrm{~m}$ within basement, which is nearly entirely recrystallized to coarse actinolite, sphene, and albite, is enriched in $\mathrm{Mg}$, has a very high $\mathrm{Fe}_{2} \mathrm{O}_{3}{ }^{\mathrm{T}}$ content $(17 \mathrm{wt} \%$ ), and has lost significant amounts of $\mathrm{Ca}, \mathrm{Si}$, and $\mathrm{Ti}$ (Sample 111504B-152R-1, 19-25 cm; Table 1). Samples exhibiting similar compositions and Fe enrichments are from 799, 916, 1041, and $1072 \mathrm{~m}$ within basement in the Leg 83 dike section (Fig. 8). All of the samples are extensively recrystallized and contain Fe-rich chlorite. The extensive recrystallization and chemical changes of these samples are consistent with their location in zones of focused fluid flow. Mottl (1983) suggested that such Fe enrichments should be found in zones of upwelling of reacted, Fe-rich hydrothermal fluids.

An extensively altered, laumontite-rich rock from $1239 \mathrm{~m}$ within basement (Sample 111-504B-163R-1, 129-132 cm; Table 1) is significantly enriched in $\mathrm{Ca}$ and has lost $\mathrm{Mg}, \mathrm{Fe}, \mathrm{Na}, \mathrm{Ti}$, and $\mathrm{Mn}$. Similar Ca-enriched rocks occur in the Leg 83 dike section (Alt et al., 1985). These are extreme cases reflecting the chemical effects of late-stage zeolite formation, which is interpreted to be the result of off-axis hydrothermal activity (Alt et al., 1986a).

\section{Oxygen Isotopes}

Oxygen isotopic data are given in Table 2 and Figure 9. The rocks are mostly depleted in ${ }^{18} \mathrm{O}$ relative to unaltered mid-ocean ridge basalt $\left(\delta^{18} 0=5.8 \%\right.$; Taylor, 1968; Muehlenbachs and
Clayton, 1972). The mean $\delta^{18} \mathrm{O}$ value for 11 samples of dark gray rocks is $4.9 \% 0 \pm 0.3 \%$, and the mean for all 15 samples is $+5.1 \%_{0} \pm 0.6 \%$, which is similar-but slightly ${ }^{18} \mathrm{O}$-depleted in comparison-to the upper part of the dike section drilled during Leg $83\left(+5.4 \%_{0} \pm 0.6 \%\right.$; Alt et al., 1986b). Using the massbalance equation of Taylor (1977) and approximating the oxygen isotopic fractionation between rocks and fluids as $\mathrm{An}_{50}$-water (O'Neil and Taylor, 1967), the ${ }^{18} \mathrm{O}$ depletions are consistent with reaction of the dikes with seawater at temperatures of $300^{\circ}-350^{\circ} \mathrm{C}$ and water/rock ratios of about 0.1 to 1 .

The light gray alteration zones and breccia are enriched in ${ }^{18} \mathrm{O}$ relative to the adjacent host rocks (Fig. 9). Similar effects in Leg 83 rocks were interpreted to be the result of progressive changes in the style of alteration of the rocks (Alt et al., 1986b). Initial seawater alteration resulted in the formation of $10 w-{ }^{18} \mathrm{O}$ phases such as chlorite and actinolite (Table 2), thereby producing ${ }^{18} \mathrm{O}$ depletions throughout the rocks. Subsequent alteration resulted in local ${ }^{18} \mathrm{O}$ enrichment through a combination of effects: (1) later stage fluids became enriched in ${ }^{18} \mathrm{O}$ relative to seawater because of the progressive reaction with basaltic dikes; (2) albite, which formed during progressive axial hydrothermal alteration, and calcic zeolites, which formed during off-axis alteration, both formed later than the Mg-rich phases at lower effective water/rock ratios and are enriched in ${ }^{18} \mathrm{O}$; and (3) later, possibly lower temperatures led to greater isotopic fractionation and ${ }^{18} \mathrm{O}$ enrichment. 
Table 1 (continued).

\begin{tabular}{|c|c|c|c|c|c|c|c|c|c|c|}
\hline \multicolumn{11}{|c|}{ Core, section, interval $(\mathrm{cm})^{\mathrm{a}}$} \\
\hline $\begin{array}{c}153 R-2 \\
30-33\end{array}$ & $\begin{array}{c}155 R-1 \\
33-36\end{array}$ & $\begin{array}{c}156 \mathrm{R}-1 \\
55-57\end{array}$ & $\begin{array}{c}159 \mathrm{R}-1 \\
10-12\end{array}$ & $\begin{array}{l}161 R-1 \\
12-14\end{array}$ & $\begin{array}{c}163 \mathrm{R}-1 \\
115-118 \\
\text { (dark) }\end{array}$ & $\begin{array}{c}163 \mathrm{R}-1 \\
129-132 \\
\text { (light) }\end{array}$ & $\begin{array}{c}165 R-1 \\
13-19\end{array}$ & $\begin{array}{l}169-1 \\
52-55\end{array}$ & $\begin{array}{l}\text { Fresh } \\
\text { glass }^{b}\end{array}$ & $\begin{array}{c}\text { Leg } 111 \\
\text { standard }^{\mathrm{c}}\end{array}$ \\
\hline 49.00 & 49.70 & 48.10 & 49.90 & 49.80 & 49.50 & 48.00 & 50.00 & 49.40 & 50.66 & 49.00 \\
\hline 15.20 & 14.60 & 14.20 & 14.30 & 15.00 & 16.00 & 15.80 & 15.10 & 14.70 & 14.96 & 16.00 \\
\hline 8.66 & 8.48 & 8.47 & 8.52 & 8.15 & 7.39 & 5.38 & 7.78 & 8.64 & 8.20 & 8.74 \\
\hline 6.30 & 6.90 & 7.50 & 7.00 & 6.80 & 6.30 & 4.20 & 7.20 & 6.50 & 8.42 & 8.20 \\
\hline 2.97 & 2.93 & 3.07 & 2.82 & 3.04 & 3.20 & 2.82 & 2.70 & 3.28 & 1.85 & 2.33 \\
\hline 0.17 & 0.18 & 0.18 & 0.18 & 0.16 & 0.15 & 0.09 & 0.18 & 0.17 & 0.17 & 0.18 \\
\hline 13.00 & 12.90 & 12.50 & 12.80 & 13.10 & 12.80 & 16.60 & 12.60 & 13.20 & 12.78 & 13.50 \\
\hline 1.82 & 1.78 & 2.22 & 1.76 & 1.61 & 1.77 & 1.28 & 1.74 & 1.53 & 2.00 & 1.67 \\
\hline 0.02 & 0.01 & 0.02 & 0.02 & 0.01 & 0.01 & 0.03 & 0.02 & 0.02 & 0.03 & 0.01 \\
\hline 0.91 & 0.99 & 0.99 & 0.98 & 0.91 & 0.97 & 0.42 & 1.00 & 0.90 & 0.97 & 0.78 \\
\hline 0.07 & 0.07 & 0.07 & 0.07 & 0.07 & 0.08 & 0.04 & 0.08 & 0.07 & 0.08 & 0.08 \\
\hline 1.30 & 1.10 & 2.30 & 1.30 & 1.30 & 1.30 & 4.30 & 1.20 & 1.40 & 0.00 & 1.10 \\
\hline 0.01 & 0.01 & 0.02 & 0.01 & 0.02 & 0.02 & 0.04 & 0.02 & 0.02 & & 0.01 \\
\hline 99.43 & 99.65 & 99.84 & 99.64 & 99.97 & 99.49 & 99.00 & 99.62 & 99.83 & $\overline{99.92}$ & 99.56 \\
\hline 1.16 & 0.93 & 2.00 & 1.08 & 1.00 & 0.93 & 5.00 & 0.77 & 1.00 & & 1.16 \\
\hline 9.97 & 10.60 & 11.40 & 10.80 & 10.60 & 10.20 & 7.49 & 10.70 & 10.50 & 11.00 & 9.22 \\
\hline 60 & 50 & 60 & 60 & 60 & 60 & 40 & 60 & 50 & & 70 \\
\hline 110 & 100 & 90 & 80 & 90 & 90 & 70 & 80 & 110 & & 120 \\
\hline 100 & 100 & 70 & 90 & 100 & 170 & 20 & 90 & 110 & & 110 \\
\hline 60 & 70 & 60 & 70 & 50 & 50 & 30 & 60 & 50 & & 60 \\
\hline- & - & - & - & - & - & - & - & - & & - \\
\hline- & 13 & - & 10 & - & 10 & - & - & - & & - \\
\hline- & - & - & - & - & - & - & - & - & & - \\
\hline- & 20 & 20 & - & - & 10 & 10 & - & 20 & & 10 \\
\hline 360 & 240 & 160 & 170 & 230 & 210 & 180 & 210 & 280 & & 350 \\
\hline 10 & - & 20 & 20 & 20 & 20 & 10 & 10 & 20 & & 10 \\
\hline 30 & 40 & 20 & 30 & 30 & 30 & 10 & 50 & 30 & & 50 \\
\hline 10 & 10 & 20 & 10 & 20 & 20 & - & 10 & 30 & & - \\
\hline 30 & 30 & 10 & 20 & 20 & 20 & - & 20 & 30 & & 40 \\
\hline 10 & 10 & 10 & 20 & 20 & 10 & 10 & - & 20 & & - \\
\hline 20 & - & 20 & 30 & 10 & 10 & - & - & 10 & & - \\
\hline 1177.9 & 1186.6 & 1196.3 & 1214.6 & 1231 & 1238.6 & 1238.8 & 1257.3 & 1275.5 & & \\
\hline 0.296 & 0.277 & 0.269 & 0.266 & 0.287 & 0.314 & 0.377 & 0.252 & 0.312 & & \\
\hline 2.95 & 2.99 & 2.93 & 3.00 & 2.94 & 2.95 & 2.75 & 2.98 & 2.98 & & \\
\hline
\end{tabular}

Quartz separated from a vein at $1225 \mathrm{~m}$ within basement has a $\delta^{18} \mathrm{O}$ value of $+8.2 \%$, within the range of values for other quartz separates from the Leg 83 section (most are from $+7.7 \%$ to $+11.7 \%$; Alt et al., 1986b). Assuming that the quartz formed in equilibrium with seawater $(0 \% 0)$ or ${ }^{18} \mathrm{O}$-enriched hydrothermal fluids $(+2 \%$; Alt et al., $1986 \mathrm{~b})$ yields temperatures of $270^{\circ}-$ $320^{\circ} \mathrm{C}$ (Clayton et al., 1972). Chlorite from a vein at $1176 \mathrm{~m}$ within basement has a $\delta^{18} \mathrm{O}$ value of $+2.4 \%$, which, for the aforementioned assumptions, indicates temperatures of about $250^{\circ} \mathrm{C}$ (Wenner and Taylor, 1971). Actinolite from a vein at $1276 \mathrm{~m}$ within basement has a $\delta^{18} \mathrm{O}$ value of $+3.8 \%$, which falls in the middle of the range of values reported for amphiboles reported from oceanic gabbros (Stakes et al., 1984).

\section{Sulfur Contents and Sulfur Isotopes}

Twelve Leg 111 samples have a mean sulfur content of $0.05 \%$ (Table 3), somewhat lower than the mean of 70 samples from the Leg 83 dike section $(0.076 \%$; Alt and Emmermann, 1985; Emmermann, 1985). The Leg 111 rocks are depleted in sulfur relative to fresh glass from mid-ocean ridge basalt $(0.081 \%$; $\mathrm{Sa}-$ kai et al., 1984), as a result of either degassing during crystallization (Moore and Fabbi, 1971) or leaching by hydrothermal fluids. As in the Leg 83 dikes, sulfur in the Leg 111 rocks is predominantly in the form of pyrite (Table 3 ). The only sample containing a significant amount of sulfate also contains visible anhydrite replacing plagioclase in the rock (111-504B-152R-1, $19-25 \mathrm{~cm}$ ).

About half of the samples contained insufficient monosulfide sulfur to analyze isotopically. Monosulfide sulfur in the analyzed samples has $\delta^{34} \mathrm{~S}$ values of $-1.0 \%$ to $+0.4 \%$, with a mean of $-0.2 \% 0 \pm 0.5 \%$ (Table 3 ). These values are the same as those of sulfur in fresh glasses from mid-ocean ridge basalt $\left(+0.1 \%_{0} \pm 0.5 \%\right.$; Sakai et al., 1984). The monosulfide sulfur in Leg 111 dikes thus represents igneous sulfide in the rocks.

Pyrite sulfur extracted from the Leg 111 dikes has $\delta^{34} \mathrm{~S}$ values that typically range from $-0.5 \%$ to $+2.0 \%$, with one value of $-4.9 \%$ and a mean of $0.0 \% 0+1.7 \%$ (Table 3 ). Pyrite and chalcopyrite samples separated from veins have similar $\delta^{34} \mathrm{~S}$ values about $0 \%$. These values are generally consistent with recrystallization of igneous sulfide with little or no isotopic fractionation. Pyrite sulfur with slightly higher values of $+1.3 \%_{0}$ to $+2.0 \% 0$ could reflect the slight positive fractionation between pyrite and basaltic sulfide in solution $\left(1.2 \%\right.$ at $300^{\circ} \mathrm{C}$; Ohmoto and Rye, 1979).

Sulfate extracted from Sample 111-504B-152R-1, 19-25 cm, has $\delta^{34} \mathrm{~S}=+19.9 \%$, and anhydrite from a vein in Sample 111504B-153R-1, 62-64 cm, has $\delta^{34} \mathrm{~S}=+20.4 \%$ (Table 3). These values are similar to those for anhydrite from veins elsewhere in the dike section (Alt et al., 1985) and are consistent with a seawater sulfur source. Precipitation of anhydrite was probably caused by the heating of seawater as it penetrated into the crust. The occurrence of anhydrite as a late fracture-filling phase is consistent with prior interpretation of anhydrite formation during off-axis seawater recharge (Alt et al., 1986a). The occurrence of anhydrite at a depth of $1176 \mathrm{~m}$ within basement indicates that unaltered seawater can penetrate to significant depths in the crust.

Anhydrite coincides with extensively recrystallized Fe-enriched rocks at depths of 1072 (Leg 83) and $1163 \mathrm{~m}$ within basement. These zones acted as foci of hydrothermal fluid flow during ax- 

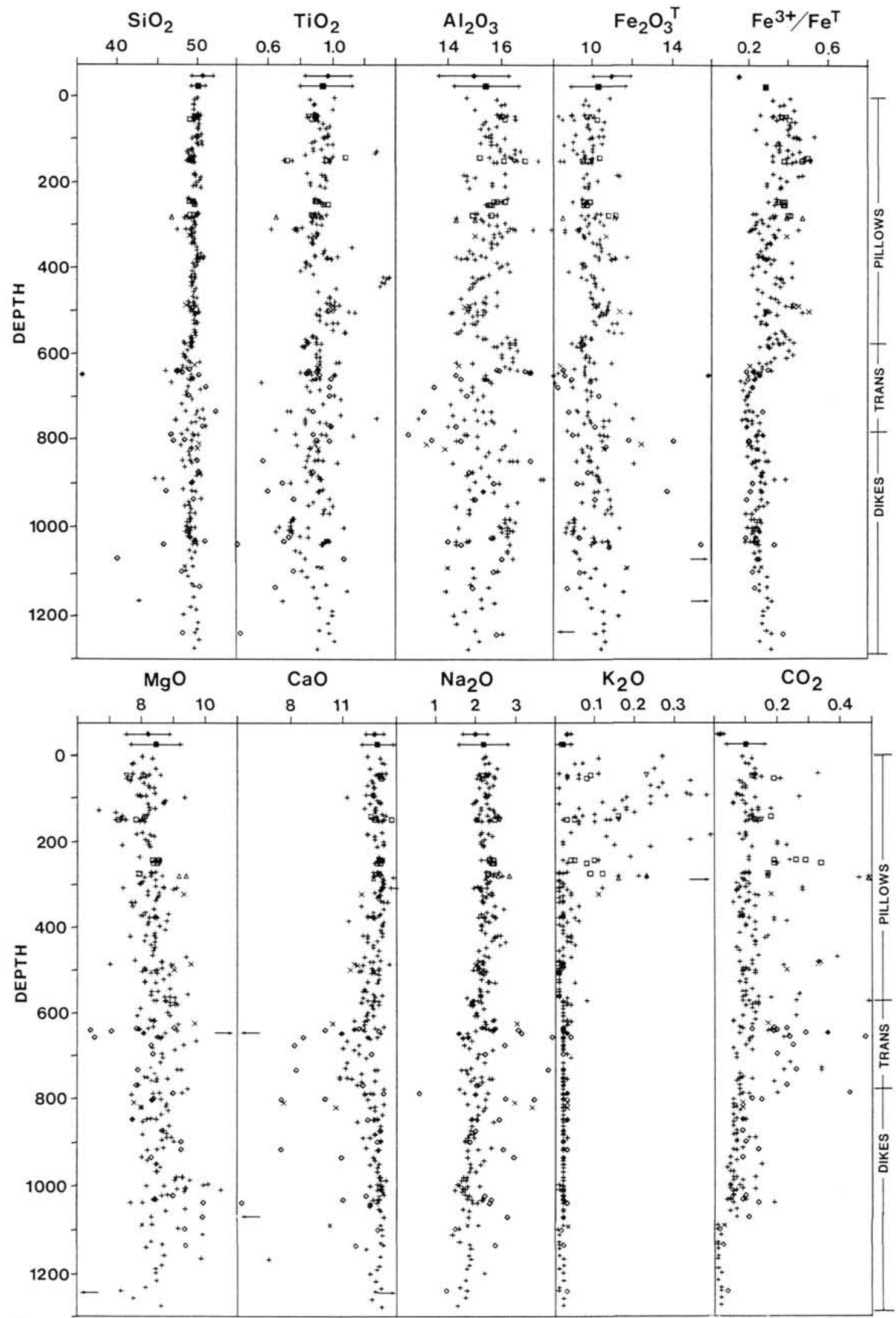

Figure 8. Whole-rock chemical analyses within basement in Hole 504B (modified from Alt et al., 1986a). Data from Leg 111 range from 1076 to $1288 \mathrm{~m}$ within basement. Plus = dark gray basalt; open square = red oxidation halo; $\mathrm{X}=$ breccia; open diamond = light gray alteration zone; solid diamond = altered glass; open triangle = zeolite-rich rock. The mean and two standard deviation range for unaltered glass (solid diamond) and least altered basalt (solid square) from the pillow section (Alt et al., 1986a) are shown for comparison. 
MINERALOGY, CHEMISTRY, AND STABLE ISOTOPIC COMPOSITIONS OF HYDROTHERMALLY ALTERED SHEETED DIKES
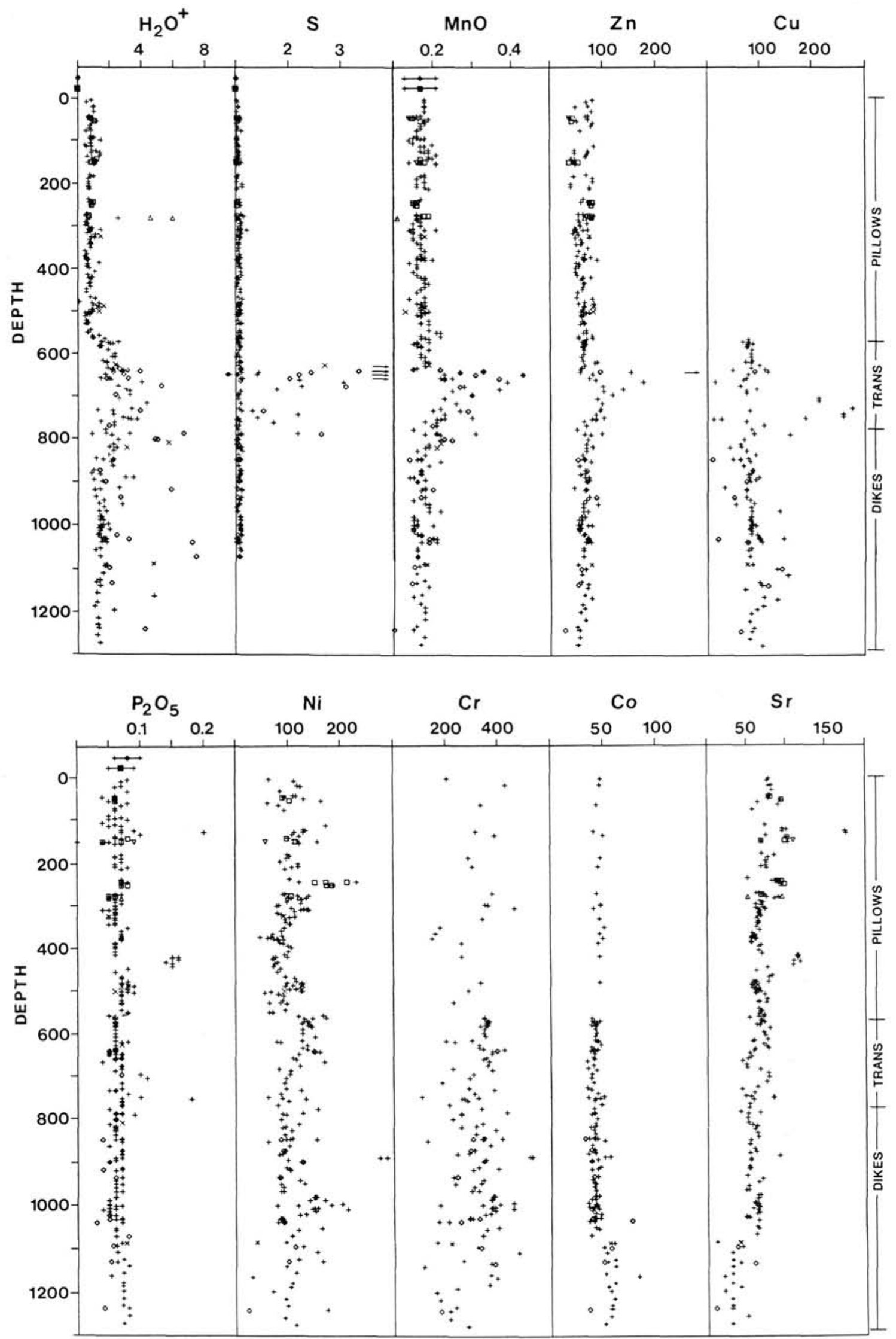

Figure 8 (continued). 
Table 2. Leg 111 oxygen isotope data, Hole 504B.

\begin{tabular}{|c|c|c|}
\hline \multirow{2}{*}{$\begin{array}{l}\text { Core, section, } \\
\text { interval }(\mathrm{cm})^{\mathrm{a}}\end{array}$} & \multicolumn{2}{|r|}{$\delta^{18} \mathrm{O}$} \\
\hline & Bulk & Vein \\
\hline $142 \mathrm{R}-1,112-117$ (breccia) & 6.4 & \\
\hline $142 R-2,5-8$ & 5.3 & \\
\hline 143R-1, 128-135 (dark) & 4.7 & \\
\hline $143 R-1,128-135$ (light) & 5.1 & \\
\hline $145 \mathrm{R}-1,40-42$ & 4.5 & \\
\hline $147 \mathrm{R}-2,6-10$ (dark) & 4.7 & \\
\hline $147 \mathrm{R}-2,6-10$ (light) & 5.5 & \\
\hline $150 \mathrm{R}-1,138-140$ & 5.2 & \\
\hline $152 R-1,19-25$ & 4.5 & \\
\hline $153 R-1,62-64$ & & 2.4 (chlorite) \\
\hline $155 \mathrm{R}-1,33-36$ & 5.3 & \\
\hline $159 \mathrm{R}-1,10-12$ & 4.6 & \\
\hline $160 \mathrm{R}-1,29-31$ & & 8.2 (quartz) \\
\hline $163 \mathrm{R}-1,115-118$ (dark) & 5.1 & \\
\hline $163 \mathrm{R}-1,129-132$ (light) & 6.3 & \\
\hline $165 \mathrm{R}-1,13-19$ & 5.2 & \\
\hline $169 \mathrm{R}-1,52-55$ & 4.5 & 3.8 (actinolite) \\
\hline
\end{tabular}

ial metamorphism, but were later refractured, allowing seawater recharge and the formation of anhydrite. Such zones of fracturing may be zones of weakness in the crust which are repeatedly reactivated, acting as circulation pathways throughout the convective cooling history of the crust.

The Leg 111 sulfide sulfur isotopic data differ somewhat from those for Leg 83 rocks. Sulfide in the transition zone has $\delta^{34} \mathrm{~S}$ values of $+0.2 \%$ to $+5.6 \%$ (mean $=+3.1 \%$ ), and sulfide values in the Leg 83 dikes range from $-0.1 \%$ to $+3.4 \%$ o (mean $=+1.3 \%$; Alt et al., 1987). These data reflect a mixture of basaltic and seawater-derived sulfur. Assuming quantitative reduction of seawater sulfate, the isotopic data indicate an average seawater contribution of $16 \%$ in the transition zone and $6 \%$ in the Leg 83 dikes. Oxidation of ferrous iron in clinopyroxene and olivine during high-temperature $\left(300^{\circ}-350^{\circ} \mathrm{C}\right)$ interaction with seawater has been proposed to account for the reduction of seawater sulfate (Alt et al., 1987). Secondary magnetite and oxidation of iron are observed in the Leg 111 rocks, but the isotopic data indicate incorporation of little or no seawater-derived sulfide in the rocks. The $\delta^{34} \mathrm{~S}$ values of vein sulfides are also basaltic (Table 3), arguing against the presence of significant amounts

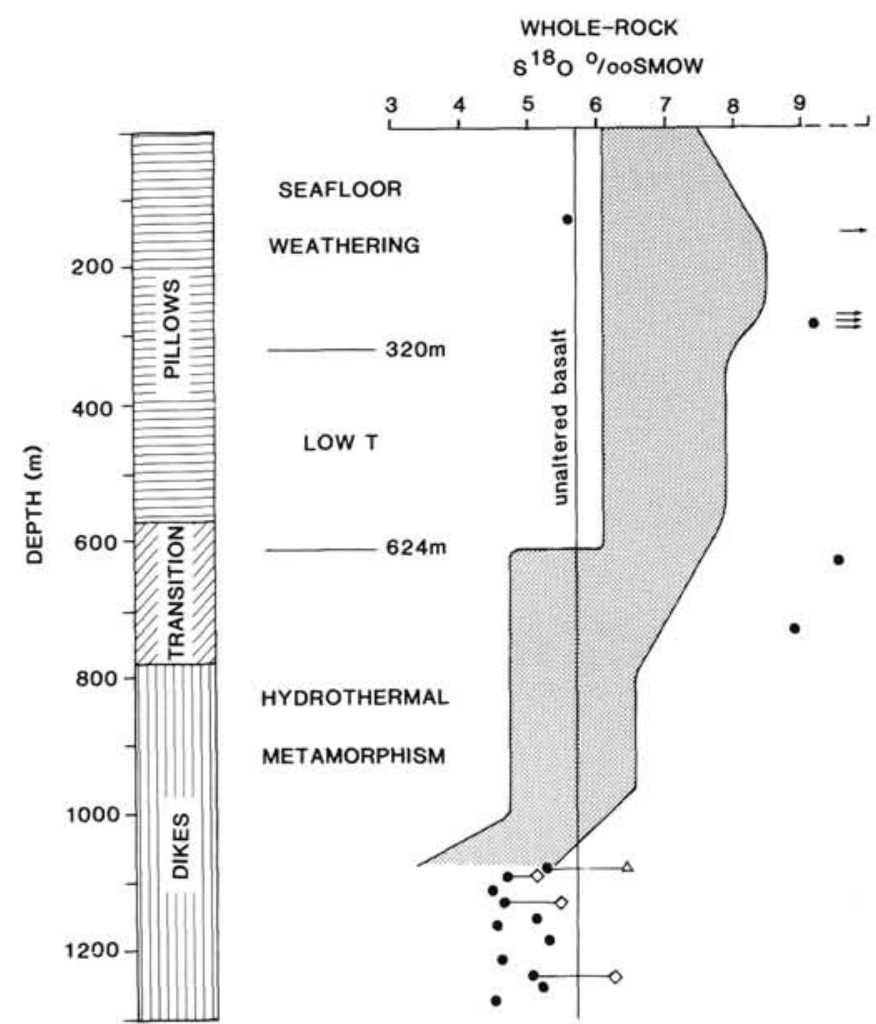

Figure 9. Whole-rock oxygen isotopic data within basement in Hole 504B. Symbols for Leg 111 samples are the same as for Figure 8, except solid circle indicates dark gray rock; lines connect samples from different parts of the same rock type. Shaded area indicates the field of 113 whole-rock analyses from Alt et al. (1986b); solid circles and arrows indicate samples that plot outside the main field.

of seawater-derived sulfide in circulating fluids. These data suggest that the oxidation effects observed in the Hole 504B dikes are not the result of reduction of seawater sulfate.

The high and variable $\delta^{34} \mathrm{~S}$ values of sulfide in seafloor hydrothermal vent fluids and associated sulfide deposits have been interpreted to be caused by a combination of processes (Shanks and Seyfried, 1987; Woodruff and Shanks, 1988). These authors propose that upwelling hydrothermal fluids contain small amounts of seawater-derived sulfide mixed with basaltic sulfide,

Table 3. Hole 504B sulfur data.

\begin{tabular}{|c|c|c|c|c|c|c|c|c|c|c|c|c|}
\hline \multirow{3}{*}{$\begin{array}{l}\text { Core, section, } \\
\text { interval }(\mathrm{cm})^{\mathrm{a}}\end{array}$} & \multirow{3}{*}{$\begin{array}{c}\text { Depth } \\
\text { (m within } \\
\text { basement) }\end{array}$} & \multicolumn{4}{|c|}{ Sulfur content (wt $\%$ ) } & \multicolumn{4}{|c|}{$\delta^{34} \mathrm{~S}$ whole rock ( $\left.\% 0 \mathrm{CDT}\right)$} & \multirow{2}{*}{\multicolumn{3}{|c|}{$\delta^{34} \mathrm{~S}$ vein minerals $(\%$ CDT) }} \\
\hline & & Monosulfide & Pyrite & Sulfate & Total & Monosulfide & Pyrite & Sulfate & Total & & & \\
\hline & & sulfur & sulfur & sulfur & sulfur & sulfur & sulfur & sulfur & sulfur & Pyrite & Chalcopyrite & Anhydrite \\
\hline $142 R-2,5-8$ & 1082.6 & 0.001 & 0.001 & - & 0.002 & & 0.4 & & 0.4 & & & \\
\hline $143 \mathrm{R}-1,128-135$ (dark) & 1090.6 & 0.005 & 0.060 & - & 0.065 & -0.3 & -0.5 & & -0.5 & & & \\
\hline $143 \mathrm{R}-1,128-135$ (light) & 1090.6 & 0.040 & 0.046 & - & 0.086 & -0.1 & 0.5 & & 0.2 & & & \\
\hline $145 \mathrm{R}-1,40-42$ & 1104.6 & 0.004 & 0.025 & - & 0.029 & & 0.2 & & 0.2 & 0.0 & -0.9 & \\
\hline 147R-2, 6-10 (light) & 1128.6 & 0.020 & 0.015 & 0.007 & 0.042 & 0.4 & 0.2 & & 0.3 & & & \\
\hline $150 \mathrm{R}-1,138-140$ & 1155.6 & 0.006 & 0.017 & - & 0.023 & & 0.4 & & 0.4 & & & \\
\hline $152 \mathrm{R}-1,19-25$ & 1162.8 & 0.011 & 0.076 & 0.057 & 0.144 & & 1.3 & 19.9 & 8.6 & & & \\
\hline $153 \mathrm{R}-1,62-64$ & 1175.5 & & & & & & & & & 0.0 & & 20.4 \\
\hline $155 R-1,33-36$ & 1186.6 & 0.014 & 0.114 & - & 0.128 & & 0.0 & & 0.0 & & & \\
\hline $161 R-1,12-14$ & 1231.0 & 0.012 & 0.023 & 0.001 & 0.036 & 0.0 & 0.0 & & 0.0 & & & \\
\hline $163 R-1,115-118$ & 1238.6 & 0.007 & 0.004 & - & 0.011 & & -4.9 & & -4.9 & & & \\
\hline $165 \mathrm{R}-1,13-19$ & 1257.3 & 0.008 & 0.037 & - & 0.045 & -1.0 & 2.0 & & 1.5 & & & \\
\hline $169 \mathrm{R}-1,52-55$ & 1275.5 & 0.010 & 0.027 & - & 0.037 & & 0.2 & & 0.2 & & & \\
\hline
\end{tabular}

Note: Blank = not analyzed; dash = below detection limit.

${ }^{a}$ Light gray alteration halos and dark gray host rocks are labeled where adjacent zones were analyzed. Other samples represent typical dark gray material, 
with total sulfide having $\delta^{34} \mathrm{~S}$ values of about $+1 \%$. Additional seawater sulfate is reduced in the walls of sulfide chimneys and in the near subsurface around the vents, leading to higher $\delta^{34} \mathrm{~S}$ values of sulfide in the vent fluids and deposits. The increase in $\delta^{34} \mathrm{~S}$ values upward in Hole 504B, from basaltic values in the dikes to $+3 \%$ in the transition zone, is consistent with this hypothesis. The transition zone is located where hydrothermal fluids upwelling through the dikes mixed with seawater circulating in the overlying pillow section. The stockworklike sulfide mineralization in the transition zone is analogous to what might be expected beneath a seafloor hydrothermal vent. During mixing, seawater sulfate may have been reduced by ferrous iron in hydrothermal fluids or in the host rocks, leading to higher $\delta^{34} \mathrm{~S}$ values in the transition zone.

\section{SUMMARY}

Leg 111 extended Hole 504B $212 \mathrm{~m}$ farther into the sheeted dike complex to $1288 \mathrm{~m}$ within basement. Alteration of the rocks recovered during Leg 111 is generally similar to that of the overlying dikes cored during Leg 83. Actinolite is somewhat more abundant in the samples from Leg 111, however, suggesting increasing temperatures with depth in the sheeted dikes. The sequence of secondary minerals in fractures is consistent with the previous model for the hydrothermal history at the site: axial hydrothermal alteration resulting in the formation of greenschist minerals was followed by seawater recharge and the formation of anhydrite locally in veins and, finally, calcic zeolites and prehnite formed during off-axis alteration. The presence of anhydrite at $1176 \mathrm{~m}$ within basement indicates that unaltered seawater can penetrate to significant crustal depths during recharge.

The rocks are generally only partly recrystallized $(<50 \%)$, but are locally more extensively altered because of enhanced initial porosity and proximity to fractures. Local zones of extensive recrystallization are enriched in $\mathrm{Fe}$ and $\mathrm{Mg}$, have lost $\mathrm{Ca}$ and $\mathrm{Si}$, and were areas of focused fluid flow during axial hydrothermal alteration. Local Ca enrichment is associated with extensive off-axis alteration.

The Leg 111 dikes are depleted in ${ }^{18} \mathrm{O}$, with a mean $\delta^{18} \mathrm{O}$ value of $+5.1 \% 0 \pm 0.6 \%$, consistent with previous results for the upper dike section and with oxygen isotopic profiles from ophiolites. Whole-rock and single-phase oxygen isotopic data indicate alteration temperatures of $250^{\circ}-350^{\circ} \mathrm{C}$ and water/rock ratios about one.

Pyrite + chalcopyrite + pyrrhotite + magnetite was the stable sulfide-oxide mineral assemblage during axial hydrothermal alteration. These minerals subsequently partially re-equilibrated at temperatures of less than $200^{\circ} \mathrm{C}$, resulting in increased amounts of pyrite and magnetite and the formation of millerite, bornite, and hematite.

The Leg 111 rocks contain a mean of $0.05 \%$ sulfur, and monosulfide and pyrite sulfur in the rocks have $\delta^{34} \mathrm{~S}$ values of $-0.2 \%_{0} \pm 0.5 \% 0$ and $0.0 \% 0 \pm 1.7 \%$, respectively. These data indicate incorporation of little or no seawater-derived sulfide in the rocks. Sulfide in hydrothermal fluids in the dikes was mostly basaltic in composition, but reduction of seawater sulfate contributed to higher $\delta^{34} \mathrm{~S}$ values in the overlying transition zone.

\section{ACKNOWLEDGMENTS}

This work was supported by a grant from JOI-USSAC and by NSF OCE-8608886. K.M.'s contribution was supported by the Canadian NSERC. The authors thank Jose Honnorez, Paul Robinson, and $\mathrm{Hi}$ toshi Sakai for helpful reviews.

\section{REFERENCES}

Alt, J. C., Anderson, T. F., and Bonnell, L., 1987. The mobility of sulfur during hydrothermal metamorphism of the oceanic crust. EOS, Trans. Am. Geophys. Union, 68:1546. (Abstract)
Alt, J. C., and Emmermann, R., 1985. Geochemistry of hydrothermally altered basalts: Deep Sea Drilling Project Hole 504B. In Anderson, R. N., Honnorez, J., Becker, K., et al., Init. Repts. DSDP, 83: Washington (U.S. Govt. Printing Office), 249-262.

Alt, J. C., Honnorez, J., Laverne, C., and Emmermann, R., 1986a. Alteration of a $1 \mathrm{~km}$ section through the upper oceanic crust, DSDP Hole 504B: the mineralogy, chemistry, and evolution of basalt-seawater interactions. J. Geophys. Res., 91:10309-10335.

Alt, J. C., Laverne, C., and Muehlenbachs, K., 1985. Alteration of the upper oceanic crust: mineralogy and processes in Deep Sea Drilling Project Hole 504B, Leg 83. In Anderson, R. N., Honnorez, J., Becker, K., et al., Init. Repts. DSDP, 83: Washington (U.S. Govt. Printing Office), 217-247.

Alt, J. C., Muehlenbachs, K., and Honnorez, J., 1986b. An oxygen isotopic profile through the upper kilometer of oceanic crust, DSDP Hole 504B. Earth Planet. Sci. Lett., 80:217-229.

Barton, P. B., and Skinner, B. J., 1979. Sulfide mineral stabilities. In Barnes, H. L. (Ed.), The Geochemistry of Hydrothermal Ore Deposits: New York (Wiley), 278-403.

Becker, K., Langseth, M. G., and Von Herzen, R. P., 1983. Deep crustal geothermal measurements, Hole 504B, Costa Rica Rift. J. Geophys. Res., 88:3447-3457.

Brimhall, G. H., 1980. Deep hypogene oxidation of porphyry copper potassium-silicate protore at Butte, Montana: a theoretical evaluation of the copper remobilization hypothesis. Econ. Geol., 75:384409.

Canfield, D. E., Raiswell, R., Westrich, J. T., Reaves, C. M., and Berner, R. A., 1986. The use of chromium reduction in the analysis of reduced inorganic sulfur in sediments and shales. Chem. Geol., $54: 149-155$

Clayton, R. N., and Mayeda, T. K., 1963. The use of bromine pentafluoride in the extraction of oxygen from oxides and silicates for isotopic analysis. Geochim. Cosmochim. Acta, 27:43-52.

Clayton, R. N., O'Neil, J. R., and Mayeda, T. K., 1972. Oxygen isotope exchange between quartz and water. J. Geophys. Res., 77:30573067.

Craig, H., 1961. Standard for reporting concentrations of deuterium and oxygen-18 in natural waters. Science, 133:1833-1834.

Craig, J. R., 1973. Pyrite-pentlandite assemblages and other low temperature relations in the Fe-Ni-S system. Am. J. Sci., 273A:496-510.

Emmermann, R., 1985. Basement geochemistry, Hole 504B. In Anderson, R. N., Honnorez, J., Becker, K., et al., Init. Repts. DSDP, 83: Washington (U.S. Govt. Printing Office), 183-199.

Gitlin, E., 1985. Sulfide remobilization during low temperature alteration of seafloor basalt. Geochim. Cosmochim. Acta, 49:1567-1579.

Honnorez, J., Alt, J., Honnorez, B. M., Laverne, C., Muehlenbachs, K., Saltzman, E., and Ruiz, J., 1985. Stockwork-like sulfide mineralization in young oceanic crust: Deep Sea Drilling Project Hole 504B. In Anderson, R. N., Honnorez, J., Becker, K., et al., Init. Repts. DSDP, 83: Washington (U.S. Govt. Printing Office), 263282.

Liou, J. G., Kuniyoshi, S., and Ito, K., 1974. Experimental studies of the phase relations between greenschist and amphibolite in a basaltic system. Am. J. Sci., 274:613-632.

Moore, J. G., and Fabbi, B. P., 1971. An estimate of the juvenile sulfur content of basalt. Contrib. Mineral. Petrol., 33:118-127.

Mottl, M. J., 1983. Metabasalts, axial hot springs, and the structure of hydrothermal systems at mid-ocean ridges. Geol. Soc. Am. Bull., 94:161-180.

Muehlenbachs, K., and Clayton, R. N., 1972. Oxygen isotope geochemistry of submarine greenstones. Can. J. Earth. Sci., 9:471-478.

Ohmoto, H., and Rye, R. O., 1979. Isotopes of sulfur and carbon. In Barnes, H. L. (Ed.), Geochemistry of Hydrothermal Ore Deposits: New York (Wiley), 509-567.

O'Neil, J. R., and Taylor, H. P., 1967. The oxygen isotope and cation exchange chemistry of feldspars. Am. Mineral., 52:1414-1437.

Puchelt, H., and Emmermann, R., 1983. Petrogenetic implications of tholeiitic basalt glasses from the East Pacific Rise and the Galapagos Spreading Center. Chem. Geol., 38:39-56.

Puchelt, H., and Hubberten, H. W., 1979. Preliminary results of sulfur isotope investigations on DSDP cores from Legs 52 and 53. In Donnelly, T., Francheteau, J., Bryan, W., Robinson, P., Flower, M., Salisbury, M., et al., Init. Repts. DSDP, 51, 52, 53, Pt. 2: Washington (U.S. Govt. Printing Office), 1145-1148. 
Sakai, H., DesMarais, D. J., Ueda, A., and Moore, J. G., 1984. Concentrations and isotope ratios of carbon, nitrogen, and sulfur in ocean-floor basalts. Geochim. Cosmochim. Acta, 48:2433-2441.

Shanks, W. C., III, and Seyfried, W. E., Jr., 1987. Stable isotope studies of vent fluids and chimney minerals, southern Juan de Fuca Ridge: sodium metasomatism and seawater sulfate reduction. J. Geophys. Res., 92:11,387-11,399.

Sinton, J. M., and Byerly, G. R., 1979. Mineral compositions and crystallization trends in DSDP Holes 417D and 418A. In Donnelly, T., Francheteau, J., Bryan, W., Robinson, P., Flower, M., Salisbury, M., et al., Init. Repts. DSDP, 51, 52, 53, Pt. 2: Washington (U.S. Govt. Printing Office), 1039-1054.

Stakes, D. S., Taylor, H. P., and Fisher, R. L., 1984. Oxygen isotope and geochemical characterization of hydrothermal alteration in ophiolite complexes and modern oceanic crust. In Gass, I. G., Lippard, S. J., and Shelton, A. W. (Eds.), Ophiolites and Oceanic Lithosphere: London (Blackwell), 199-214.

Syers, J. K., Chapman, S. L., Jackson, M. L., Rex, R. W., and Clayton, R. N., 1968. Quartz isolation from rocks, sediments, and soils for determination of oxygen isotopes composition. Geochim. Cosmochim. Acta, 32:1022-1025.
Taylor, H. P., 1977. Water/rock interactions and the origin of $\mathrm{H}_{2} \mathrm{O}$ in granitic batholiths. J. Geol. Soc. London, 133:509-558.

1968. The oxygen isotope geochemistry of igneous rocks. Contrib. Mineral. Petrol., 19:1-71.

Ueda, A., and Sakai, H., 1983. Simultaneous determinations of the concentration and isotope ratio of sulfate- and sulfide-sulfur and carbonate-carbon in geological samples. Geochem. J., 17:185-196.

Wenner, D. B., and Taylor, H. P., 1971. Temperatures of serpentinization of ultramafic rocks based on ${ }^{18} \mathrm{O}-{ }^{16} \mathrm{O}$ fractionation between coexisting serpentine and magnetite. Contrib. Mineral. Petrol., 32: 165-185.

Woodruff, L. G., and Shanks, W. C., III, 1988. Sulfur isotope study of chimney minerals and vent fluids from $21^{\circ} \mathrm{N}$, East Pacific Rise: hydrothermal sulfur sources and disequilibrium sulfate reduction. $J$. Geophys. Res., 93:4562-4572.

Date of initial receipt: 12 April 1988

Date of acceptance: 31 October 1988

Ms 111B-114 